\title{
ITTALYA'NIN BOĞAZLARI
}

\section{STRAITS OF ITALY}

DOI: 10.21492/inuhfd.294945

Anıl ÇAMYAMAÇ*

\section{ÖZET}

Konumunun gösterdiği üzere, İtalya, Akdeniz'in ve onun ticaret güzergâhlarının merkezinde bulunmaktadır. Saçak adalarla çevrili Akdeniz'e uzanan yarımada şeklindeki yapısı, İtalya'ya, ülkesini çevreleyen önemli boğazlar sağlamıştır. Bu boğazların önemi, konumlarından ötürü, sadece İtalya'nın kendisi için değil, aynı zamanda dünya toplumu içindir. Böylece, İtalya'nın tavrını hem 1982 tarihli Birleşmiş Milletler Deniz Hukuku Sözleşmesi öncesindeki toplantılarda, hem de bu konuda 1982 tarihli Sözleşmeden sonraki düzenlemeleri çerçevesinde irdelemek akılcı olacaktır.

Anahtar Kelimeler/Terimler: Messina Boğazı, Messina İstisnası, Uluslararas1 Seyrüseferde Kullanılan Boğazlar, Transit Geçiş, 1982 tarihli Birleşmiş Milletler Deniz Hukuku Sözleşmesi.

\section{ABSTRACT}

As its location reveals, Italy sits on the center of the Mediterranean Sea and its trade routes. Its peninsular structure projecting into the Mediterranean Sea surrounding with scattered islands provides Italy with important straits circumscribed its land territory. The importance of these straits, because of their location, is not only for Italy itself, but also for the World community. Hence, it would be wiser to investigate Italy's position towards its straits, particularly focusing on the meetings before the UNCLOS, and the Italian regulations in this very subject after the UNCLOS, as well.

Keywords: Straits of Messina, Messina Exception, Straits Used for International Navigation, Transit Passage, UNCLOS.

\section{Giriş}

Dünya ticaretinin \%90'nın denizler üzerinden gerçekleştirilmesi, deniz yollarının güvenliğinin ve geçiş serbestisinin sağlanmasının önemini, tartışmasız bir biçimde, ortaya koymaktadır. Hâl böyle olunca, farklı denizleri ve deniz alanlarını birbirine bağlayan coğrafî alanlar olan boğazların önemi bir kat daha artmış olmaktadır. Artan bu önemin iki yönü olduğu unutulmamalıdır. Bir tarafta boğaza kıyısı olan devletler ve onların ihtiyaçları, bir tarafta boğazlardan yararlanan devletler ve başta seyrüsefer olmak üzere onların ihtiyaçları bu iki temel yönü oluşturmakta ve bunların arasında orta bir yol bulunması gerekmektedir. Aranılan bu orta yolun 1982 Birleşmiş Milletler Deniz Hukuku Sözleşmesi

\footnotetext{
* LLM ve PhD in Dokuz Eylül Üniversitesi Sosyal Bilimler Enstitüsü Kamu Hukuku Anabilim Dal1.
} 
çerçevesinde bulunduğu ifade edilebilir. Özellikle, denizci büyük güçlerin olabildiğince serbestçe geçmeyi arzu ettikleri boğazlarda, diğer geçiş rejimleriyle mukayese edildiğinde liberal olarak adlandırılabilecek transit geçiş rejiminin kıyı devletlerini koruyacak mekanizmalarla kabûl edilmesi bu durumu kanıtlamıştır.

Tarihin ilk çağlarından beri dünya ticaretinin ve medeniyetlerinin en temel merkezlerinden biri konumunda bulunan Akdeniz'in ortasında konumlanan İtalya'nın çevresindeki boğazların statüsünün, özellikle Akdeniz'in mahiyeti göz önüne alındığında, önem arz ettiği kuşku götürmez bir gerçek olarak ifade edilebilir. Bu düşünceden yola çıkılarak bu kısa çalışmada İtalya'ya ait boğazlar uluslararası deniz hukuku çerçevesinde incelenmeye çalışılacaktır. Bu çerçevede, öncelikle Akdeniz ele alınarak kısaca tanıtılmaya çalışılacak, sonrasında İtalya'nın coğrafî durumu, ele alınacak boğazlarla birlikte betimlenerek, boğazlara ilişkin 1982 tarihli Birleşmiş Milletler Deniz Hukuku Sözleşmesinde yer verilen genel düzenleme irdelenecektir. Sonrasında ise, İtalya'nın boğazlara ilişkin tutumu ve özellikle de 1982 Sözleşmesinin oluşması sırasındaki açıklamaları ve önerileri değerlendirilip, İtalya'ya ait boğazların bu düzenlemeler çerçevesindeki durumu incelenerek görüşümüz açıklanacaktır.

\section{Akdeniz ve Önemi}

Üç büyük kıtanın ortasında konumlanarak onları birbirinden ayıran, belki daha doğru bir ifadeyle onları birleştiren Akdeniz kapladığ 865.000 mil $^{2}$ lik yüzölçümü alanıyla ${ }^{1}$ önemli bir denizdir. Kuzeyinde Avrupa Kıtas1, güneyinde Afrika Kıtası ve doğusunda Asya kıtasıyla çevrili Akdeniz'in tek doğal çıkışı, batısında konumlanarak kendisini Atlantik Okyanusuyla bağlayan Cebelitarık Boğazıdır. Bunun dışında, güney doğusunda dünyanın en önemli ve işlek suyollarından birini teşkil eden Süveyş Kanalı konumlanmaktadır ki, Akdeniz böylelikle önce Kızıl Denize sonrasında ise Bab-al Mandep Boğazıyla Umman Denizi ve Hint Okyanusuna bağlanmaktadır.

Akdeniz kendi içerisinde birçok deniz alanı barındırmakta ve önemli boğazlarla farklı denizlere bağlanmaktadır. Öncelikle, yarı-kapalı veya kapalı deniz alanı ${ }^{2}$ olarak mütalâa edilen Akdeniz kendi içerisinde

${ }^{1}$ Bkz. ALEXANDER L.M., Regionalism and the Law of the Sea: The Case of SemiEnclosed Seas, Ocean Development \& International Law, vol. 2/2, 1974, s. 171.

21982 tarihli Birleşmiş Milletler Deniz Hukuku Sözleşmesi m. 122 ve 123. Bu düzenlemelerde "kapalı ve yarı-kapalı deniz" kavramında yer alan bu iki farklı konsept 
aynı niteliği haiz şu deniz alanlarını içermektedir’ Ege Denizi, Marmara Denizi, Adriyatik Denizi, İyon/Yunan Denizi, Tiren Denizi, Liguryen Denizi, İber/Balerik Denizi ve Alboran Denizi. ${ }^{4}$ Bunun dışında, Akdeniz, Karadeniz'e de Ege Denizi ve Türk Boğazları yoluyla bağlanmaktadır. ${ }^{5}$

Akdeniz'i çevreleyen 22 devlet vardır: İspanya, Fransa, Monako, İtalya, Slovenya, Hirvatistan, Bosna-Hersek, Karadăg, Arnavutluk, Yunanistan, Türkiye, Suriye, Lübnan, İsrail, Misır, Libya, Tunus, Cezayir, Fas, Malta, Kuzey Kıbris Türk Cumhuriyeti ve Güney Kıbrıs Rum Kesimi. Bu devletler dışında, İngiltere'nin Kıbrıs'ta yer alan üsleri ${ }^{6}$ ve Cebelitarı çerçevesinde İngiltere'nin de resmin içerisinde yer alması gerekmektedir. Öte yandan, Gazze Şeridi bağlamında, her ne kadar devlet olarak statüsü tartışılsa da, Filistin'in de dikkate alınması gereklidir. ${ }^{7}$ Tüm bu devletlere Karadeniz'e kıyısı olan devletler de eklenince sayının daha da artacağı muhakkaktır. Bu itibarla, hem Karadeniz'e, hem Akdeniz'e

arasında bir ayrımın olmadığı, ilgili bu kavramın bir bütün olarak ele alındığ gözlenmektedir. Zaten, konuya ilişkin bu yönlü bir ayrımın yapılmasına dair İran önerisinin kabûl edilmediği ve 1982 tarihli Sözleşme metnine aktarılmadığ hatırlanmalıdır. Bu önerinin metni için bkz. "Iran: Draft Articles on Enclosed and SemiEnclosed Seas", Document A/COLF.62/C.2/L.72, 21 August 1974, s. 237.

3 Seršić'in Adriyatik Denizi özelinde inceleme gerçekleştirdiği makalesinin adı, hatırlanacağı üzere, "Adriyatik Denizi: Yarı Kapalı Bir Denizde Yarı-Kapalı Deniz" başlığını taşımaktadır. Bkz. SERŠIĆ M., The Adriatic Sea: Semi-Enclosed Sea in a Semi-Enclosed Sea, in La Méditerranée et le droit de la mer à l'aube du 21e siècle/The Mediterranean and the Law of the Sea at the Dawn of the 21st Century, edited by Cataldi, Bruylant, Bruxelles, 2002, s. 329-347.

${ }^{4} \mathrm{Bu}$ deniz alanlarının sınırlarına ilişkin olarak bkz. "Limits of Oceans and Seas", 3rd edition, International Hydrographic Organization Special Publication no: 28, Monte Carlo, 1953, s. 16-18.

${ }^{5}$ Karadeniz'in bir başka çıkışı yoktur. Yâni, Karadeniz doğal yollarla sadece Akdeniz’e çıkışı olan bir deniz alanıdır. Bununla beraber, 1990'ların ortalarında açılan Ren-MainTuna Kanalı sayesinde nehir yoluyla Karadeniz ve Kuzey Denizi arasında bir bağ kurulmuştur. Ayrıca, Don-Volga Kanal sistemi dâhilinde Karadeniz'in kuzeyde Baltık Deniziyle ve güneydoğuda Hazar Deniziyle nehir bağlantıları söz konusudur. Bunun dışında, Karadeniz'in Kerç Boğazıyla kuzeyindeki Azak Körfezi/Denizine de bağlantısı söz konusudur.

${ }^{6}$ İngiltere'nin Kıbrıs Adasında yer alan iki üssü Akotiri ve Baf üsleridir. Bu üslerin hukukî statüsüne dair bkz. PELLET A., The British Sovereign Base Areas, Cyprus Yearbook of International Law, 2012, s. 57-72.

7 Gerek Gazze Şeridi bağlamında Filistin, gerek Cebelitarık ve Kıbrıs'taki üsleri bağlamında İngiltere'nin Akdeniz çerçevesindeki durumlarına ilişkin kısa bir değerlendirme için bkz. BLAKE G.H., Mediterranean Micro-Territorial Disputes and Maritime Boundary Delimitation, in Il regime giuridico internazionale del mare Mediterraneo, edited by Leanza, Dott A. Giuffrè Editore, Milano, 1987, s. 112-114. 
kıyısı olan tek devlet Türkiye'dir. Bunun dışında, Karadeniz'e kıyısı olan devletlerin, Rusya Federasyonu haricinde, diğer denizlere kıyıları da bulunmamaktadır. Bu durum da, Karadeniz'e kıyısı olan devletleri diğer açık denizlere çıkış için öncelikle Akdeniz'e muhtaç kılmaktadır. Bu çerçevede, Türkiye haricinde Karadeniz'e kıyısı olup Akdeniz Havzasına dâhil edilebilecek devletlere şu şekilde yer verilebilir: Bulgaristan, Romanya, Ukrayna, Rusya Federasyonu ve Gürcistan. ${ }^{8}$ Tabiî ki, Akdeniz'e kıyısı olan devletler haricinde, bu deniz alanını çevreleyen üç kıtada da, bu deniz alanına çıkışı olan ve bu denizden yoğunlukla ticaretlerinde yararlanan denize kıyısı olmayan devletler ${ }^{9}$ de vardır. $\mathrm{Bu}$ çerçevede, Akdeniz'in ard-ülkesinin (hinterland) oldukça geniş ve gelişmiş olduğu kabûl edilmelidir.

Akdeniz'in eskiden beri ticaretin merkezi olduğunu iddia etmek yanıltıcı olmasa gerektir. Roma İmparatorluğu, Osmanlı İmparatorluğu gibi dünya tarihine damga vurmuş önemli İmparatorlukların etki alanı olduğu gibi, ortaçağ ticaretinin en önemli süjeleri Venedik, Ceneviz gibi İtalyan şehir devletleri, daha eskiçağlarda ticarette önemli rol oynamış Yunan devletleri, Fenikeliler Akdeniz'in kendi çağlarında efendileri olmuştur. Ayrıca, bir dönem en önemli ticaret güzergâhı olan ve Doğunun zenginliklerinin Avrupa'ya taşındığı İpek Yolu'nun bitiş noktasını teşkil eden Akdeniz, keşifler zamanında bir ara önemini yitirmiş olsa da, Süveyş Kanalının açılmasıyla tekrar önemini kazanmıştır. ${ }^{10} \mathrm{Bu}$ bağlamda, Atlantik Okyanusu ve Hint hattâ Pasifik Okyanusuyla ticaretin merkezinde yer almaktadır. Kuzey Avrupa'nın önemli liman kentleri

\footnotetext{
82008 yılında Rusya ve Gürcistan'1 karşı karşıya getiren çatışma sonrasında de facto olarak kurulmuş olan ve başta Rusya Federasyonu olmak üzere sınırlı sayıda devletin tanıdığı Abhazya akıllara gelebilir. Fakat, çok kısıtlı sayıda devletin tanıdığı, dahası bir dış müdahale sonucunda kurulmuş olan bu birimin bir devlet olarak mütalâa edilmek suretiyle bu listelemede yer alması düşünülmemiştir.

${ }^{9} \mathrm{Bu}$ devletler, kabaca, şu şekilde sıralanabilir: Çad, Mali ve Nijer (Afrika Kıtası), Azerbaycan, Kazakistan ve Türkmenistan (Asya Kitası); Avusturya, Çek Cumhuriyeti, İsviçre, Kosova, Liechtenstein, Macaristan, Makedonya, San Marino, Sirbistan, Slovakya ve Vatikan (Avrupa Kıtası). Bu konuda daha ayrıntılı bir değerlendirme için bkz. ÇAMYAMAÇ A., Denize Kıyısı Olmayan ve Coğrafî Açıdan Elverişsiz Devletlerin Hukukî Durumu, Adalet Yayınevi, Ankara, 2012, s. 286-287.

10 Akdeniz'in ticaret bakımından önemi konusunda bkz. QUÉGUINER J., The Mediterranean as a Maritime Trade Route, Ocean Management, vol. 3/2, 1978, s. 179189. Ayrica, bkz. ABBADI A.K., Security and Cooperation in the Mediterranean Basin, Ocean Development \& International Law, vol. 14/1, 1984, s. 56-58; TRUVER S.C., The Strait of Gibraltar and the Mediterranean, Sijthoff \& Noordhoff, Alphen aan den Rijn, 1980.
} 
Rotterdam (Hollânda), Antwerp (Belçika), Hamburg (Almanya), Bremen (Almanya) ve Felixstowe (İngiltere) limanlarından Çin'in önemli liman ve üretim merkezlerine giden temel güzergâh yolunu teşkil eden Akdeniz, Ortadoğu ve hattâ Kafkaslardaki doğal kaynakların, daha açık ifadeyle petrol ve doğal gazın taşındığı temel suyollarından birini de teşkil etmektedir. $^{11}$

\section{II. İtalya'nın ve Boğazlarının Genel Coğrafì Özellikleri}

İtalya, Kuzey Akdeniz'de Akdeniz'in tam ortasına denk gelecek şekilde Avrupa kıtasından çizme şeklinde uzanan Apenin Yarımadası üzerinde konumlanmış, dünyanın önemli devletlerinden biridir. $^{12}$ Çizmenin doğusu Adriyatik Deniziyle çevriliyken, güneydoğusunda Yunan Denizi, batısında Tiren Denizi ve Kuzeybatısında ise Liguryen Denizi konumlanmıştır.

Çizmenin güney batı ucuna denk gelen kesimde sadece İtalya'nın değil, Akdeniz en büyük adası Sicilya konumlanmaktadır. Yine, batı kesiminde Tiren Denizinde İtalya'ya ait Akdeniz'in ve İtalya'nın ikinci büyük adası Sardunya bulunmaktadır. Bunun haricinde, gerek İtalyan anakarası, gerek bu iki büyük adanın çevresinde İtalya'ya ait irili ufaklı adalar, adacıklar ve ada grupları (takımadalar) bulunmaktadır. Bunlar içerisinde, Uscita ve Pantelleria Adaları ile Toskana Takımadaları, Aeolian Takımadaları, Pelagie Takımadaları ve Akdeniz'in ortasından fışkıran ve en önemlileri Stromboli olan yanardağ adaları ${ }^{13}$ ön plânda gelmektedir.

11 Tabiî ki, Akdeniz'in kendi bünyesindeki önemli limanları da es geçilmemelidir. Akdeniz'deki birçok önemli liman arasında öne çıkanlar şunlardır: Algerias Limanı, Valencia Liman1, Malta Serbest Limanı, Gioia Tauro Liman1, Cenova Limanı, Barselona Limanı, Trieste Limanı, Pire Limanı ve İskenderiye Limanı.

${ }^{12}$ İtalya dünyanın önemli sanayileşmiş devletlerinden biridir. Avrupa Birliği'nin önemli üyelerinden biri olan İtalya aynı zamanda öncesinde G 7'ler olarak bilinen günümüzde Rusya Federasyonu'nun katılımıyla G 8'ler olan grubun da üyesidir. Birleşmiş Milletler gelişmişlik endeksi tarandığında İtalya'nın 27. sırada olduğu gözlenmektedir. Bkz. "Human Development Report", United Nations Development Programme, New York, 2015, $\quad$ s. $208 \quad$ via http://hdr.undp.org/sites/default/files/2015_human_development_report_1.pdf (ziyaret tarihi: 16/02/16).

13 İtalya'da aktif, yarı-aktif ve aktivitesi sona ermiş birçok yanardağ bulunmaktadır. Bunların bir kısmı denizde konumlanmıştır. Denizde konumlanan bu yanardağların en önemlileri Ischia, Stromboli ve Vucano'dur. Ayrıca, bu yanardağ adalarından Filicurdi, Monte Cristo, Salina, Ischia (Toskana Adalarından biri) gibileri denizde bağımsız adalar konumundayken, bir kısmı sualtında konumlanmaktadır. Sualtında konumlananlar arasında Marsili, Campi Flegrei mar Sicilia, Isola Ferdinandea sıralanabilir. Özellikle 
İtalya yarımadası ve adaları arasında birçok boğazın konumlandığı ve tüm dar deniz alanlarında olduğu gibi her bir boğazın yoğun olarak kullanıldığı düşünülürse, Akdeniz gibi ticaretin ve dolayısıyla gemi seyrüseferinin çok işlek olduğu bir deniz alanında yer alan bu boğazlardaki geçişin ve uygulanacak kuralların önemi kendiliğinde kanıtlanmış olmaktadır. ${ }^{14}$

İtalya'nın boğazları ${ }^{15}$, coğrafî ayrım bir yana, iki kıyının da İtalya'ya ait olup olmamasına göre bir ayrıma tâbi tutulabilecektir. ${ }^{16} \mathrm{Her}$

belirtilmelidir ki, Isola Ferdinandea veya bilinen diğer adıyla Graham Adası belirli zamanlarda harekete geçerek Akdeniz'in yüzeyine çıkmaktadır. En son çıkışında, devletler arasında egemenlik sorununa bile yol açmıştır. Ischia, Stromboli, Vulcano ve Campi Flegria'ya ilişkin genel bilgi için bkz. SANTACROCE R. \& CRISTOFOLINI R. \& La VOLPE L. \& ORSI G. \& ROSI M., Italian Active Volcanoes, Episodes, vol. 26/3, 2003, s. 228-233.

${ }^{14}$ Hiç kuşku yoktur ki, en az bir kıyısı İtalya'ya ait olan boğazlar dışında da, Akdeniz'in önemi göz önüne alındığında, bu deniz alanında birçok önemli boğaz bulunmaktadır. Bunlar arasında Akdeniz'in Atlantik Okyanusuna tek doğal çıkışını teşkil eden Cebelitarı, Menorka Kanalı, Hırvatski Kanalı, Mijetski Kanalı, Karpatsos Boğazı, Kithera Boğazı,Türk Boğazları ve Kerç Boğazı gibi boğazlar akıllara ilk gelenlerdir.

15 Boğazlara ilişkin en kapsamlı çalışmalardan birini ortaya koyan Alexander, ilgili eserinde, İtalya'nın boğazlarını altı adet olarak sıralamaktadır. Bkz. ALEXANDER L.M., Navigational Restrictions within the New LOS Convention: Geographical Implications for the United States, Offshore Consultants Inc., Rhode Island, 1986, s. 210. $\mathrm{Bu}$ çerçevede, Alexander, bu kapsamlı çalışmasında, Piambioni Boğazına yer vermemiştir. Öte yandan, belirtilmelidir ki, yaptığımız araştırmalarda, gerek İtalyan anakarası yakınında bulunan bazı İtalyan adalarıyla ana kara arasında coğrafî olarak varolan, gerek Sicilya'nın batı ve kuzeyindeki ada grupları ve Sicilya arasında coğrafî olarak varolan dar geçişlere spesifik isimler verilmiş olduğu görülmüştür ki, dolayısıyla bu dar deniz geçiş alanları bu çalışmada ele alınamamıştır. Bununla beraber, Napoli’ye yakınlarındaki Ischia Adasıyla di Vivara Adası arasında konumlanan ve en dar yerinde 1.2 deniz mili genişliği haiz olan Ischia Kanalı ile yine aynı bölgede bulunan Procida Adası ile anakara arasında konumlanan 1.5 deniz mili genişliğindeki di Procida Kanalı dikkate değer boğazlardır. Bahsedilen ilk boğazda seyrüsefer tam ortadan oldukça güvenli bi biçimde gerçekleştirilebilirken, ikinci boğazda birçok sığlık alan olması sebebiyle 9 metre derinliğe sahip ana geçiş kanalının 0.2 metre genişliğe sahip olduğu ve böylelikle seyrüseferin çok da güvenli olmadığı belirtilmektedir. Tüm bu bilgiler ve daha fazlası için bkz. "Sailing Directions (En Route)-Western Mediterranean", publication no: 131, 16th edition, Virginia, 2014, s. 295 via http://msi.nga.mil/MSISiteContent/StaticFiles/NAV_PUBS/SD/Pub131/Pub131bk.pdf (ziyaret tarihi: 01/09/16). (Bundan sonra "Sailing Directions") Adı geçen bu iki boğazında uluslararası seyrüseferde kullanılmamasından ötürü uluslararası boğaz statüsünü haiz olmadığı aşikârdır.

${ }^{16} \mathrm{Bu}$ ayrım ve coğrafî konuma göre yapılacak ayrımlar hariç, meselâ önemlerine göre de boğazlar arasında bir ayrım yapılabilir. Her ne kadar, bu yedi boğazın önemi günümüzde 
iki kıyısı da İtalya'ya ait boğazlar ve sadece tek kıyısı İtalya'ya ait boğazlar. İlk kategori dâhilinde şu boğazlara yer verilebilir: Messina Boğazı, Piambioni Boğazı ve Sicilya Boğazı. İkinci kategori dâhilinde ise şu boğazlar sıralanabilecektir: Bonifacio Boğazı (Korsika Adası/Fransa), Korsika Boğazı (Fransa), Malta Boğazı (Malta) ve Otranto Boğazı (Arnavutluk).

Konunun daha rahat anlaşılması bağlamında bu boğazların coğrafî özelliklerinin ayrıca tasvir edilmesi ve kısaca ortaya konulması, kuşkusuz, yararlı olacaktır:

-Messina Boğazı: İtalyan anakarasının güneyinde bulunan Calibra ile Sicilya Adası arasında konumlanmış, Tiren Denizi ile İyon Denizini birbirine bağlayan Messina Boğazı en dar yerinde beş deniz milinin biraz üzerinde genişliğe sahip olan, kıyılara yakın bölgeler hariç derinliğin 150 ilâ 300 kulaç arasında değiştiği, 30 deniz mili uzunluğunda bir boğazdır. ${ }^{17}$

- Piambioni Boğazı: Diğer adı Elba Boğazı olan, Liguryen Denizi ile Tiren Denizini birbirine bağlayan ve Toskana Takımadalarını teşkil eden adalardan biri olan Elba Adas1 ile İtalyan anakarası arasında konumlanan Piambioni Boğazı beş deniz mili genişliğindedir. ${ }^{18}$

inkâr edilemese de, Brüel Avrupa'da yer alan boğazları bu şekilde bir ayrıma tâbi tutarken, bu ayrımdan İtalya'ya ait boğazlar da, en azından büyük bir bölümü de, nasibini almıştır. Brüel'in yaptığı ayrım bağlamında Messina Boğazı, Bonifacio Boğazı ve Otranto Boğazı birincil öneme sahip boğazlarken, Sicilya Boğazının ikincil öneme sahip boğazlar arasında kendisine yer bulduğu gözlenmektedir. Bkz. BRÜEL E., International Straits-ATreatise on International Law: The General Legal Position of International Straits, vol. I, NYT Nordisk Forlag/Sweet \& Maxwell Ltd., Copenhagen, 1947, s. 44. Tabiî ki, bu değerlendirme İtalyan Boğazlarına ilişkin ve 1940'lar ve 1950’ler aritmetiğinde gerçekleştirilmiştir. Birincil ve ikincil öneme sahip boğazlar ayrımı, her ne kadar sübjektif ve değişken nitelikte olsa da, günümüzde hâlen en azından belirli bir raddeye kadar devam ettirilen bir ayrımdır. Öte yandan, bu çeşit bir ayrımın değişken ve sübjektif niteliğini sergilemesi açsından Alexander'in Sicilya Boğazının Batı ve Doğu Akdeniz'in ayrımını ortaya koyma açısından önemli olarak nitelendirmesini belirtmek yeterli olacaktır. Bkz. ALEXANDER, 1986, s. 276. Benzer şekilde, Abbadi Akdeniz'deki Cebelitarık ve Türk Boğazlarının yanı sıra, Sicilya'yı da önemli boğazlar arasında saymıştır. Bkz. ABBADI, s. 56.

${ }^{17}$ KENNEDY R.H., A Brief Geographical and Hydrographical Study of Straits Which Constitute Routes for International Traffic, in United Nations Conference on the Law of the Sea-Official Documents vol. I: Preparatory Documents, Document A/CONF.13/6 and Add. 1, Geneva, 1958, s. 135-136. Ayrica, bkz. SPADI F., The Bridge on the Straits of Messina: "Lowering" the Right of Innocent Passage?, International \& Comparative Law Quarterly, vol. 50/2, 2001, s. 411.

${ }^{18}$ Bkz. LÓPEZ MARTÍN A.G., International Straits: Concept, Classification and Rules of Passage, Springer, Heidelberg, 2010, s. 95. 
- Sicilya Boğazı: İtalya'nın güneyinde İtalya'ya ait Sicilya Adası ile Tunus anakarası arasında konumlanan Sicilya Boğazı, 53 deniz mili genişliğinde bir boğazdır. ${ }^{19}$ Boğazın ortasında İtalya'ya ait Pantelleria Adası bulunmaktadır.

- Bonifacio Boğazı: Korsika ve Sardunya Adaları arasında konumlanan Bonifacio Boğazının yaklaşımlarıyla birlikte toplam uzunluğunun 22 mil, sadece kendisi hesap edildiğinde 10 mil olduğu, en dar yerinde genişliğinin 2.23 deniz mili olduğu, derinliğinin ise 27 ilâ 40 kulaç arasında değiştiği ve ayrıca boğazda bulunan kayalıkların ve sert akıntıların seyrüseferi oldukça güçleştirdiği ifade edilmektedir. ${ }^{20}$

- Korsika Boğazl/Kanall: Bir tarafta İtalya'ya ait Elba Adası beri tarafinda Fransa'ya ait Korsika Adasının arasında bulunan Korsika Boğazı en dar yerinde 27 deniz mili olup Liguryen Denizi ile Tiren Denizini birbirine bağlamaktadır. ${ }^{21}$

- Malta Boğazı: Sicilya ve Malta adaları arasında konumlanan 44 deniz mili genişliğinde bir boğazdır. ${ }^{22}$

- Otranto Boğazı: Adriyatik Denizinin girişini teşkil eden 57 mil uzunluğundaki Otranto Boğazının en dar yeri 40 deniz miliyken, orta kesimindeki derinliğin 550 metre ilâ 1081 metre arasında değiştiği belirtilmektedir. $^{23}$

\section{Boğazlara İlişkin 1982 tarihli Birleşmiş Milletler Deniz Hukuku Sözleşmesi Çerçevesindeki Düzenlemelerin Kısaca Değerlendirilmesi}

Uluslararası boğazlara ilişkin 1982 tarihli Birleşmiş Milletler Deniz Hukuku Sözleşmesinde açıkça bir tanım öngörülmemiştir. Bu çerçevede, uluslararası hukukun, daha açık bir ifadeyle 1982 tarihli Birleşmiş Milletler Deniz Hukuku Sözleşmesi'nin ilgilendiği boğazlar hangileridir? Bu konuda, Pharand'in 1977 tarihli makalesinde gerçekleştirmiş olduğu

\footnotetext{
${ }^{19}$ Bkz. ibid., s. 85 .

${ }^{20}$ Bkz. KENNEDY, s. 136-137. Ayrica, bkz. TREVES T., Transit Passage and Protection of Environment in the Strait of Bonifacio, in A Law for the Environment: Essays in the Honour of Wolfgang E. Bruhenne, edited by Kiss \& Bruhenne-Guilmin, IUCN: The World Conservation Union, Norwich, 1994, s. 121.

${ }^{21}$ Bkz. LÓPEZ MARTÍN, s. 85.

${ }^{22}$ Bkz. ibid., s. 85.

${ }^{23}$ Bkz. VIO I., The Strait of Otranto: The Legal Regime, Navigational Aspects and Geopolitical Significance for the Adriatic States, in Proceedings of the Symposium on Straits Used for International Navigational, edited by Öztürk \& Özkan, Ofis Matbaas1, İstanbul, 2002, s. 54. Ayrica, bkz. LÓPEZ MARTíN, s. 85.
} 
tanım, mutadis mutandis, şu şekilde uyarlanabilir: uluslararası boğazlar, 24 deniz milini aşmayan, iki açık deniz veya münhasır ekonomik bölgeyi veya bir açık deniz veya münhasır ekonomik bölgeyi bir başka devletin karasularıyla bağlayan ve uluslararası seyrüseferde kullanılan boğazlardır. $^{24}$

Boğazlar, ayrı birer deniz yetki alanı teşkil etmeyen; aksine, içlerinde genişlikleri oranında birden fazla deniz yetki alanı barındıran coğrafî oluşumlardır. Boğazların, deniz hukukunun düzenleme alanına girmesinin temel nedeni geçiş rejimleridir. Özellikle, karasuları genişliğinin artması ve sonucunda uluslararası seyrüseferde kullanılan birçok önemli boğazın kıyı devlet veya devletlerinin karasuları dâhiline girmesi, ilgili bu boğazlardan seyrüsefer serbestisi sorununu beraberinde getirmiştir. 1982 tarihli Birleşmiş Milletler Deniz Hukuku Sözleşmesi çerçevesinde belirli konuları kapsayan paket anlaşmanın (package deal) ${ }^{25}$ öngörüldüğü, bunun da en önemli kısımlardan birinin artan karasuları genişliği karşısında boğazlardan liberal bir geçiş sistemi öngören transit geçiş hakkının benimsemesi olduğu gözlenmektedir. Bu itibarla, 1982 tarihli Birleşmiş Milletler Deniz Hukuku Sözleşmesi III. Bölümünü teşkil eden ve toplam 12 maddeden oluşan "Uluslararası Seyrüseferde Kullanılan Boğazlar" başlığı altında üç tür geçiş rejimi söz konusu edilmiştir $^{26}$ : Transit geçiş rejimi ${ }^{27}$, (askıya alınamayan) zararsız geçiş

${ }^{24}$ Bkz. PHARAND D., International Straits, Thesaurus Acroasium, vol. 7, 1977, s. 72.

${ }^{25}$ Paket anlaşma konusuna dair daha geniş ve ayrıntılı açıklamalar için bkz. CAMINOS H. \& MOLITOR M.R., Progressive Development of International Law and the Package Deal, American Journal of International Law, vol. 79/4, 1985, s. 871-890; EVENSEN J., The Working Methods and Procedures in the Third United Nations Conference on the Law of the Sea, Recueil des cours, vol. 199, 1986-IV, 1986, s. 435-451; SANGER C., Ordering the Oceans: The Making of the Law of the Sea, University of Toronto Press, Avon, 1987, s. 36-38.

${ }^{26}$ Farklı nedenlerle daha farklı sayı ve çeşitlilikte geçiş rejimi öngören yazarlar da yok değildir. Bu konudaki farklı görüşlerin daha ayrıntılı ele alınıp değerlendirmesi için bkz. ÇAMYAMAÇ, s. 278-279 dipnot: 1164.

${ }^{27}$ Transit geçiş rejimine dair daha ayrıntılı değerlendirmeler için bkz. BOCZEK B.A., The A to $\mathrm{Z}$ of International Law, The Scarecrow Press, Inc., Lanham, 2010, s. 312-314; BORDUNOV V.D., The Right of Transit Passage under the 1982 Convention, Marine Policy, vol. 12/3, 1988, s. 219-230; CAMINOS H. \& COGLIATI-BANTZ V.P., The Legal Regime of Straits: Contemporary Challenges and Solutions, Cambridge University Press, Cambridge, 2014, özellikle s. 151-224; LÓPEZ MARTÍN, s. 151-198; MAHMOUDI S., Transit Passage, Max Planck Encyclopedia of Public International Law, on-line edition, edited by Wolfrum, 2010 via www.mpepil.com (ziyaret tarihi: 
rejimi ve statüleri uzun süreden beri varolan bir antlaşmayla düzenlenen boğazlardan o antlaşmada ortaya konulmuş olan geçiş rejimi.

Transit geçiş hakkı, 1982 tarihli Birleşmiş Milletler Deniz Hukuku Sözleşmesi çerçevesinde oluşturulan sistemde, temel geçiş rejimi olarak ortaya konulmuştur. ${ }^{28} \mathrm{Bu}$ bağlamda, istisnaî durumlar haricinde, transit geçiş hakkı tüm boğazlarda uygulanacaktır ve bu geçiş rejiminin özellikle karasularından zararsız geçiş rejimiyle mukayese edildiğinde daha liberal bir geçiş sistemi olduğu da görülecektir. Bu itibarılyla, transit geçiş hakkında denizaltılar sualtından geçiş yapabilecekken ${ }^{29}$, uçaklar için de uçuş serbestisi ${ }^{30}$ öngörülmektedir. ${ }^{31}$ Öte yandan, transit geçiş hakk1, karasularından zararsız geçiş hakkından farklı olarak, hiçbir sebeple kıyı devletince askiya alınamaz ve engellenemez. ${ }^{32}$

Askıya alınamayan zararsız geçiş hakkı, ancak belirli özellikler gösteren boğazlar için söz konusudur. Yâni, istisnaî bir geçiş sistemi olarak düzenlenmiştir. 1982 tarihli Birleşmiş Milletler Deniz Hukuku Sözleşmesi düzenlemesi çerçevesinde iki tür boğazda bu tür geçiş söz konusu olmaktadır: bir devletin kendine ait adası ile anakarası arasında bulunan ve adanın açık deniz tarafinda ilgili boğazın sağladığı kolaylıkta

04/10/10); ÖZMAN A., Deniz Hukuku I: Kaynaklar, Kişiler, Nesneler, Ulusal Deniz Alanları, Turhan Kitabevi, Ankara, 2006, s. 366-373.

${ }^{28} 1982$ tarihli Birleşmiş Milletler Deniz Hukuku Sözleşmesi m. 38/2'de transit geçiş hakkı şu şekilde ifadesini bulmaktadır: "Transit geçiş, açık denizin veya münhasır ekonomik bölgenin bir kesimi ile diğer bir açık deniz veya münhasır ekonomik bölge kesimi arasında, boğazdan, sadece sürekli ve çabuk geçiş amacıyla, bu bölümle uyumlu olarak seyrüsefer ve uçuş özgürlüğ̈̈nün kullanılması anlamını taşır".

${ }^{29}$ Esasen konuya dair açık bir düzenleme bulunmamakla birlikte 1982 Birleşmiş Milletler Deniz Hukuku Sözleşmesi m. 39/1(c)'de şu düzenlemeden yola çıkılmak suretiyle denizaltıların da sualtından geçebilecekleri kabûl edilmektedir: “... normal usûllerince ...”. Bununla birlikte, konuya ilişkin açık bir düzenleme olmamasını eleştiren yazarlar da vardır. Bkz. REISMAN M.W., The Regime of Straits and National Security: An Appraisal in International Lawmaking, American Journal of International Law, vol. 74/1, 1980, s. 71-75.

${ }^{30} 1982$ tarihli Birleşmiş Milletler Deniz Hukuku Sözleşmesi m. 38.

${ }^{31}$ Farklar ana metinde belirtilen bu üç farkla (metinde bu dipnotla atıf yapılan cümle ve ona müteakip cümlede belirtilen farklar) sınırlı değildir, şüphesiz. Transit geçiş rejimiyle karasularından zararsız geçiş rejimi arasında varolan farklara ilişkin olarak daha ayrıntılı bir değerlendirme için bkz. SHARMA O.P., The International Law of the Sea: India and the UN Convention of 1982, Oxford University Press, New Delhi, 2009, s. 86-87.

321982 tarihli Birleşmiş Milletler Deniz Hukuku Sözleşmesi m. 44. 
bir geçişin bulunduğu boğazlar ${ }^{33}$ ve bir açık deniz veya münhasır ekonomik bölge alanını bir devletin karasularıla bağlayan boğazlar ${ }^{34}$. Adının da ortaya koyduğu üzere askıya alınamayan zararsız geçiş hakkının karasularındaki zararsız geçiş hakkından en temel farkı askıya alınamaması, kıy devletleri tarafından engellen(e)memesidir.

1982 tarihli Birleşmiş Milletler Deniz Hukuku Sözleşmesi m. 35/c'de yer verilen ve üçüncü tür geçiş rejimi olarak değerlendirilebilecek uzun süreden beridir varolan antlaşmalarda geçiş rejimi düzenlenen boğazlar, esasen bakıldığında sayıları çok fazla olmayan boğazları kapsamaktadır. ${ }^{35}$ Bu boğazlardaki geçiş rejimi, ilgili boğazların durumunu ele alan ve uzun süreden beridir mevcut antlaşmalarda yer verilen bu spesifik geçiş rejimleridir. ${ }^{36}$

331982 tarihli Birleşmiş Milletler Deniz Hukuku Sözleşmesi m. 38/1. Messina istisnası olarak da adlandırılan bu düzenlemeye ilişkin aşağıda daha ayrıntılı bir değerlendirme yapilacaktır.

34 1950’lerde Tiran Boğazının İsrail gemilerinin geçişine kapatılmasıyla I. Deniz Hukuku Konferansı öncesinde ve esnasında konu ele alınmış ve 1958 tarihli Cenevre Karasuları ve Bitişik Bölge Sözleşmesi m. 16/4 maddesi bu çerçevede kabûl edilmiştir. Bu maddenin paralel düzenlemesi 1982 tarihli Birleşmiş Milletler Deniz Hukuku Sözleşmesinde de kendisine 45/1(b) maddesi olarak yer bulmuştur. Tiran Boğazı için getirilen bu düzenlemeye ilişkin tartışmalar bağlamında ayrıntılı değerlendirmeler için bkz. GIOIA A., Gulf of Aqaba, Max Planck Encyclopedia of Public International Law, on-line edition, edited by Wolfrum, 2010 paragraflar 12-17 via www.mpepil.com (ziyaret tarihi: 08/10/10); SELAK C.B.Jr., A Consideration of the Legal Status of the Gulf of Aqaba, American Journal of International Law, 52/4, 1958, s. 660-698; ZEIDAN A.L., The Emergence of the Gulf of Aqaba Problem, Revue égyptienne de droit international, vol. 35, 1979, s. 1-65.

${ }^{35}$ Doktrinde, en azından tartışmasız olarak, bu nitelikte sayılan dört boğaz söz konusudur: Türk Boğazları, Danimarka Boğazları, Magellan Boğazı ve Åland Boğazı. Bu konu hakkında daha ayrıntılı değerlendirmeler için bkz. ÇAMYAMAÇ, s. 280; ÖZBEK D., Article 35(c) Straits of the UN Law of the Sea Convention, in Navigating Straits: Challenges for International Law, edited by Caron \& Oral, Brill Nijhoff, Leiden, 2014, s. 180-198; ÖZMAN, s. 377-380.

${ }^{36}$ Türk Boğazları için 1936 tarihli “Montreux Boğazlar Sözleşmesi”, Danimarka Boğazları için 1857 tarihli "Kopenhag Sözleşmesi", Magellan Boğazı için 1881 tarihli "Buenos Aires Antlaşması" ve Åland Boğazı için 1921 tarihli "Aland Adasının Tahkim Edilmemesi ve Tarafsızlaştırılması Hakkındaki Anlaşma" söz konusu olan antlaşmalardır. Bunlar dışında, günümüzde bazı boğazlara ilişkin sözleşmelerin akdedildiği gözlenmektedir. Esasen, 1982 tarihli Birleşmiş Milletler Deniz Hukuku Sözleşmesinde bu duruma engel bir kural olmadığı gibi Sözleşmenin genel nitelikli düzenlemeleri kendisine aykırı olmamak kaydıyla kabûl ettiği de bir gerçektir. Burada dikkat edilmesi gereken husus, gerçekleştirilen bu antlaşmaların 1982 tarihli Birleşmiş Milletler Deniz Hukuku Sözleşmesinin uluslararası seyrüseferde kullanılan boğazlara 
1982 tarihli Birleşmiş Milletler Deniz Hukuku Sözleșmesinin ilgili maddeleri çerçevesinde, boğazların kıyıdaşı devletlerin hak ve ödevleri (m. $42 \& 44$ ), aynı şekilde gemileri geçiş yapan devletlerin hak ve ödevleri (m. 39) gibi hususlara yer verildiği gibi, m. 43'te boğazların kıyıdaşı devlet veya devletlerle ilgili boğazları kullanan devletlerarasında işbirliğine de gidilmesi öngörülmektedir.

IV. Italya, Deniz Hukuku ve İtalya'nın Özellikle Boğazlara İlişkin Konularda Deniz Hukukuna Etkisi

Medeniyetlerin merkezi İtalya, bu unvanına yakışır şekilde deniz hukukunu her zaman etkilemiştir. ${ }^{37}$ Her ne kadar kamu deniz hukuku olarak adlandırılan kuralların Roma döneminde fazlaca ele alınmadığı bildirilse de, İtalyanların etkileri özellikle karasularının tartışılması konusunda ortaçağ aritmetiğinde ciddî bir yer tutmaktadır. Sassoferrato'lu Bartolus denizlerde yaklaşık 100 deniz millik ${ }^{38}$ bir yetki alanını savunurken, Feodal hukukta karasuları anlayışını başlattığı ifade edilen ${ }^{39}$ öğrencisi Ubaldi'li Baldus ise daha geniş tutulabileceğini belirtmesine rağmen 60 deniz millik bir yetki alanını savunmuştur. ${ }^{40}$ Denizi ülke kavramı içinde değerlendirerek bu konuda büyük bir değişime sebep olan Gentilis de, 100 deniz mili genişliği savunurken, de Perno ise gözün görebildiği yere kadar uzanan bir yetki alanını savunmuştur. ${ }^{41}$

ilişkin hükümlerine, daha spesifik olmak gerekirse, transit geçiş rejimine dair kurallara aykırılık teşkil etmemesi yeterli olacaktır. Nitekim, 1982 tarihli Birleşmiş Milletler Deniz Hukuku Sözleşmesi m. 311/2 \&3'te açık biçimde bu yönlü genel bir düzenleme de söz konusudur. Bu yönlü paralel görüşler için bkz. SCOVAZZI T., Management Regime and Responsibility for International Straits with Special Reference to the Mediterranean Straits, Marine Policy, vol. 19/2, 1995, s. 144.

${ }^{37}$ Deniz ticaret hukukunun ayrı tutulduğunun altı çizilmelidir. Günümüzün deniz ticaret hükümlerinin bir kısmının Roma Hukuku kökenli olduğu bilinen bir gerçektir. Meselâ, "genel avarya"ya dair günümüz düzenlemeleri Roma Hukukuna dayanmaktadır.

38 Íki günde kat edilen yol olarak ifade etmiştir.

${ }^{39}$ Bkz. FENN P.T.Jr., Origins of the Theory of Territorial Waters, American Journal of International Law, vol. 20/3, 1926, s. 472.

${ }^{40}$ Bkz. SWARZTRAUBER S.A., The Three-Mile Limit of Territorial Waters, Naval Institute Press, Annapolis, 1972, s. 10-11. Ayrica, bkz. FENN, s. 473-478; HAQUE E. \& HASSAN D., Maritime Boundary Delimitation: A Normative Standard?-Part I: Historical Development of the Legal Regime, Environmental Policy \& Law, vol. 44/5, 2014, s. 435.

${ }^{41}$ Bkz. FENN, s. 478 vd; HAQUE \& HASSAN, s. 435. 
Tüm bunlar bir kenara, bu makalenin özelinde ele alınması gereken, boğazlar konusuna ilişkin hükümlerin ortaya çıkışında ${ }^{42}$, özellikle de III. Deniz Hukuku Konferansı esnasında İtalya'nın oynadığı rol olmalıdır. ${ }^{43}$ III. Deniz Hukukuna ilişkin boğazlara dair görüşme tutanakları incelendiğinde, İtalya'nın oldukça etkili bir biçimde davrandığ gözlemlenmektedir. ${ }^{44}$

İlk olarak, Deniz Yatağı Komitesinin 19 Temmuz ilâ 27 Ağustos 1971 tarihleri arasında gerçekleşen II. oturumunda İtalyan delegesinin söz alarak oldukça uzun bir konuşma yaptığı görülmektedir. ${ }^{45}$ Delege, özetle, 1958 tarihli Cenevre Karasuları ve Bitişik Bölge Sözleşmesinin 14 ve 16. maddelerinde yer verilen, kıy devletlerinin ve uluslararası toplumun çıkarları arasında mâkul bir uzlaşı sağlayan, zararsız geçiş hakkının, yeknesak bir biçimde uygulanmadığının, karasuları genişliği ve ilgili kavramların farklı yorumlanması çerçevesinde çeşitli şekillerde algılandığının altını çizmiş; bir yandan karasularının genişliğinin artmasının daha fazla sayıda boğazı zararsız geçiş hakkına tâbi kılacağını, öte yandan bu geçiş rejiminin oldukça öznel bir şekilde yorumlandığını vurgulamıştır. Delege, ülkesinin, birçok devletin revizyona ilişkin önerilerine, tüm etkenlerin göz önüne alınması şartıyla, karşı çıkmayacağını belirtirken, bu etkenler arasında öne çıkanları ise kıyı devletinin korunmasına ilişkin hak ve ödevler, açık deniz serbestilerine dair uluslararası toplumun çıkarları ve özel bir önemin atfedilmesi gereken boğazların siyasî konumlarının gözetilmesi olarak sıralamıştır. Açıklamalarının devamında, delege, boğazlara ilişkin hukukî sorunların 24 deniz mili genişliğinin altındaki boğazlarda söz konusu olduğunu, bu genişliğin ötesindeki boğazlarda her zaman bir açık deniz kuşağı olacağını bildirmiş ve ülkesinin, olabildiğince dar genişlikteki karasularını

${ }^{42}$ Treves, I. Deniz Hukuku Konferansı esnasında, özellikle boğazlar konusunda fazla etkili olmayan İtalya'nın III. Deniz Hukuku Konferansında oldukça aktif olduğuna işaret etmiștir. Bkz. TREVES T., Italy and the Law of the Sea, in The Law of the Sea: The European Union and Its Member States, edited by Treves \& Pineschi, Martinus Nijhoff Publishers, The Hague, 1997, s. 334.

43 Ele alınan konunun bir gereği olarak bu makalede, gerek III. Deniz Hukuku Konferansında, gerek konferans dışında o dönemde İtalya'nın deniz hukukuna ilişkin diğer konulardaki görüş ve saptamalarına dair bir değerlendirmeye gerek görülmemiştir.

${ }^{44}$ Bu konuda çok daha kısa bir değerlendirme için bkz. TREVES, 1997, s. 334-335.

${ }^{45}$ Bkz. "Straits Used for International Navigation-Legislative History of Part III of the United Nations Convention on the Law of the Sea", volume I, United Nations: Office for Ocean Affairs and the Law of the Sea, New York, 1992, s. 41-43. (Bundan sonra "Straits ...", vol. I) 
savunduğuna dikkat çekerek, yeknesak olarak ve her yerde uygulanmak koşullarıyla en fazla 12 deniz millik karasularını kabûl edebileceğini eklemiştir. Bunun sonucu olarak, 24 deniz mili genişliğini aşan boğazların düzenlemelerden tamamen muaf tutulmasını talep etmiş ve 12 deniz milinin ötesindeki her yerde olduğu gibi bu boğazlarda da uluslararası toplumun denizlerin serbestliğini her zaman tanımaları gerektiğini ifade etmiştir. Boğazların hukukî açıdan ele alınması bağlamında, uluslararası seyrüsefere dair her türlü rejimin temelinde farklı çıarlar arasında bir dengenin yattığına, boğazlardan seyrüsefer konusunda ise özellikle uluslararası toplumun genel çıkarları ve her bir devletin belirli çıkarlarını beraberce gözetecek uygun bir çözümün gereğine işaret ettikten sonra, tam da bu yüzden tüm boğazlar birmiş gibi hareket edilemeyeceği gibi, standart düzenlemelerin kabûlü bağlamında tek bir çözümün de söz konusu olamayacağını ifade etmiştir. Bununla beraber, delegeye göre, bir diğer uç nokta olan tek tek boğazlara göre kuralların oluşturulmasından da kaçınılması gereklidir. Böylece, esas yapılması gerekenin, bazı boğazlar için belirli özelliklerin ortaya konulması suretiyle genel ilkeler yaratılmaya çalışması gereği olduğuna işaret edilmiş̧ir. Bu çerçevede de, delegeye göre, ilk tür boğazlar, devletlerin açık deniz serbestilerinden yararlanması ancak ilgili sulardan tam bir geçiş serbestisinin öngörülmesini gerektiren boğazlardır. Daha açık bir ifadeyle, ya karasularından açık denizlere çıkış sağlayan boğazlar ya da kapalı denizlerin çıkışı konumundaki boğazlar bu gruba dâhildir. Bir geminin açık denizlere tek çıkış yolunu teşkil eden veya başka bir çıkışı olmayan denizden tek çıkışı teşkil eden boğazlardaki geçişin kıyılarındaki egemen haklara sahip devletçe veya devletlerce engellenmesinin kabûl edilemezliği de, delege tarafından, bu itibarla, açıklamalarına ilâve edilmiştir. Bu tür kapalı deniz alanlarına ilişkin örneklendirmeye giden İtalyan delege, bu denizlerin ağızlarında yer alan boğazların, seyrüsefer serbestisine engel teşkil etmemesi gereğinin altını çizmiştir. Her ne kadar, ilgili kıyı devletlerinin egemenliğine ciddî sınırlama getirse de, bu gibi durumların uluslararası toplumun genel çıkarlarının öncelikli hâle gelebilmesinin temel nedenini oluşturduğunu ifade eden delege, konuşmasını, uluslararası toplumun temel çıkarlarının ön plânda olmadığı bazı durumlarda ise dengenin ayarlanmasının zorluğunu dile getirerek sürdürmüş ve kıyılarının birbirinden oldukça uzak konumlandığı boğazlar için veya kıyıları insan yapımı bir yapıyla bağlanan boğazlar için aynı tür davranış1 beklemenin zor olduğunu eklemeyi ihmal etmemiştir. Böylelikle, delege, muhtemel başka bir ayrımı da gündeme getirmekte ve 
boğazlarda kıyıları sadece bir devlete ait olan veya iki veya daha fazla devlete ait olan şeklinde bir farklılaşmaya gitmektedir. Kıyıları iki veya daha fazla devlete ait kılınmış boğazlarda suların paylaşımı gibi daha farklı sorunların da çıkabileceğine işaret eden İtalyan temsilci, tasvir ettiği tüm bu durumlar sonucunda, sorunun iki yönünün ele alınması gerektiğine dikkat çekerek, bir yanda hukukî açıdan ilgili denizin kapalı bir deniz olmaması için doğal olarak varolan suyollarını teşkil eden boğazların olduğunu ve bunların korunmalarının uluslararası toplumun genel çıarını teşkil etmesinden ötürü azamî oranda dikkate alınması gerektiğini; öte yanda ise, sınırlı genişliği olan, kıyıları ve suları tek ve aynı devlete ait olan boğazların geldiğini ve bunların ulusal boğaz niteliğinde olduğunu vurgulamıştır. Delege, bu sonuncu durumda kıyı devletinin çıkarlarının, uluslararası toplumunkilerin de ihlâl edilememesi koşuluyla, ağır bastığını ileri sürerek, anılan bu boğazlarda tam bir seyrüsefer serbestisinin sağlanmasının kıyı devletinin ne güvenliğiyle ne de malî ve ticarî çıkarlarıyla uyumlu olduğunu belirtmiş̧tir. Bu anlatılarını, kıyı devletinin uluslararası toplumun genel çıkarlarının gerektirmediği bir durumda neden karasularının bir parçasındaki egemenliğinden vazgeçmesi gerektiğini sorarak sürdürmüş ve zaten uluslararası toplumun bu genel çıkarlarının 1958 tarihli Cenevre Karasuları ve Bitişik Bölge Sözleşmesinde tanınan zararsız geçiş hakkıyla güvence altına alındığının altını çizerek sadece sınırlı sayıda boğaz için geçerli olan bu hakkın hukuken ve uygulama açısından herhangi bir soruna yol açmayacağını ifade etmiştir. Delege, yine de herhangi tek bir genişliğin telâffuz edilmemesi gerektiğini de belirtmeyi ihmal etmemiştir. Tüm bunları belirttikten sonra, delege, hâlîhazırda herhangi bir karasuları genişliğinin belirlenmemesini de firsat bilerek, kullanılan genel karasuları genişliğinin iki katına tekâbül eden 6 deniz mili genişliği boğazlar için önermiş ve bu tür boğazlar için karasularında kullanılan zararsız geçiş hakkının değiştirilmemesi gerektiğini vurgulayarak, bazı delegelerin zararsız geçiş hakkının revize edilmesini önerdiğini, kendi ülkesinin teklifini göz önüne alarak, her ne kadar zararsız geçiş hakkının önemli olmadığı düşünülebilse de, çok uzun yıllardır kullanılan bir kavramın bu kadar kolaylıkla terk edilmesinin ve dahası karasuları rejimi bağlamında yenilenmesinin zor olduğuna inandığını iletmiş̧tir. Daha sonra, delege, karasuları genişliğinin arttırılması söz konusu olacaksa zararsız geçiş hakkının mutlaka korunmas1 gereğinin önemi üzerinde durmuştur. Buna karşıllı, 1958 Sözleşmesinde kavramın gereği gibi düzenlenmediğini, ülkesinin daha objektif bir veriye dayanan bir formülasyona yardım edebileceğini 
belirterek, bahsetmiş olduğu iki uç noktanın arasında da bir kuşak olacağını, bunun da serbest geçişin sağlandığı bir kuşak olması gerektiğini ifade etmiştir. Tüm bu bağlamda, sabırlı olunması ve çok iyi bir araştırmanın yapılarak iki uç nokta arasında kalan bazı boğazların tespit edilmesi gerektiğini savunmuştur. Bu çerçevede, Etiyopya Delegesinin önerisini $^{46}$ desteklediğini belirtirken, delege, konuya dair Amerika Birleşik Devletleri önerisini ise denizdeki seyrüsefer serbestisiyle birlikte aynı zamanda uçuş serbestisini de beraberinde talep ettiği için ve bu ikinci konunun Alt Komitenin yetkisi altında olmadığına işaret ederek eleştirmiştir. Konuyu daha da açan delege, hukukî anlamda deniz ile hava seyrüseferlerinin birbiriyle çok da bağlantılı olmadığına, nitekim 1958 düzenlemelerinde uçuş hakkına yer verilmemiş olduğuna dikkat çekmiş ve konunun esasen 1944 Chicago Sözleşmesinde ve onun da öncesinde 1919 Paris Sözleşmesinde ele alındığını ortaya koymuştur. Sonunda delege, deniz seyrüseferi ve hava seyrüseferine aynı rejimin uygulanmasının zor olduğunu, bu yüzden de deniz hukukunun kodifiye edilmesine ilişkin bu yeni çabada uçuş serbestisinin ele alınmaması gereğini belirterek sözlerine son vermiştir.

İkinci Alt Komitenin 28 Şubat ilâ 30 Mart 1972 tarihleri arasında gerçekleşen ilk oturumunda İtalyan delege söz alarak konuya ilişkin olarak, özetle, şu hususları dile getirmiştir ${ }^{97}$ : İlgili durumlarının tamamen aynı olmadığından bahisle tüm boğazların yeknesak biçimde bir düzenlemeye tâbi tutulmasının gerçekçi ve doğru bir yaklaşım olmadığını, tek bir kıyı devletinin toprakları arasında uzanan, dar ve seyrüsefer güzergâhları bağlamında sadece talî nitelik kesbeden boğazların ulusal boğazlar olarak mütalâa edilmesi gerektiğini ve bunlar dâhilinde uluslararası toplumun çıkarlarının çok da korunması gerekmediğini; buna karşılık, ilgili kıyı devletinin çıkarlarının ise mümkün olabilen en azamî düzeyde korunması gerektiğini belirtmiş ve bu tür ulusal boğazlardan seyrüsefer serbestisinin öngörülmesinin kıyı devletlerinin güvenlik, kamu düzeni ve kamu sağlığı konularındaki çıkarlarıyla birlikte, malî ve ticarî çıkarlarıyla da uyumsuz olacağına işaret etmiştir. Konuşmasının devamında, İtalyan delege, bazı boğazların uluslararası seyrüsefer için doğal ve zarurî bir yol teşkil ettiğini ve eğer ki geçiş engellenirse hukukî açıdan bakıldığında bazı denizlerin kapalı denizler hâline geleceğini vurgulamıştır. $\mathrm{Bu}$ tür durumlarda açık olarak uluslararası toplumun

\footnotetext{
${ }^{46}$ Etiyopya Delegesinin ilgili açıklamaları için, bkz. "Straits ...”, vol. I, s. 36-37.

${ }^{47}$ Bkz. “Straits ...”, vol. I, s. 57-58.
} 
çıkarlarının üstün geleceği ve kıyı devletlerinin de diğer tüm ulusların meşrû çıkarlarının uygun tatmini karşısında kendi ulusal çıkarlarının ikinci plâna atılmasını kabûl etmesi gerektiğini ifade ederek, sonuçta bu tür boğazların serbest uluslararası seyrüsefere açık boğazlar olduğunun altını çizmiştir. Daha sonrasında, delege, bu iki uç durum arasında uluslararası toplumun çıkarlarıyla ilgili kıyı devletlerinkiler arasında hakça bir dengenin bulunmasını gerektiren birçok örneğin olduğuna işaret etmiş ve 56 devletin sponsoru olduğu Deniz Yatağı Komitesinin II. Alt Komitesine sunulan teklifin bu tür bir çözümü sağlamaya yönelik yeterli genişliğe sahip olduğunun altını çizmiştir.

1973 yılındaki ilk oturumda II no'lu Alt Komitede görüş sunan devletlerden biri konumundaki İtalya, delegesi aracılığıyla, uluslararası önemi haiz boğazlardan seyrüseferde tam bir serbestliğin sağlanması ihtiyacını vurgulayarak çok sınırl genişliğe sahip veya her iki kıyısı üzerinde yetkiyi haiz devlet için baskın bir biçimde ulusal çıkarın söz konusu olduğu boğazlarda bu serbestinin zararsız geçiş hakkına dönüşeceğinin altını çizmiştir. ${ }^{48}$

2 Temmuz ilâ 4 Ağustos 1973 tarihleri arasında gerçekleştirilen ikinci oturumda İtalyan delegesi boğazlara ilişkin şu taslak maddeleri sunmuştur ${ }^{49}$ :

“(a) Paragraf (b)'deki hükümlere tâbi olarak, tüm gemiler ve tüm hava araçları, açık denizin iki kesimini bağlayan veya bir yabancı devletin karasularını açık denizin bir kısmıyla bağlayan boğazlarda veya bunların üzerinde transit amacıyla (geçişlerde) açık denizlerde mevcut olan aynı seyrüsefer ve uçuş serbestisinden yararlanacaktır.

(b) Transit serbestisi trafiğin engellenmesinden imtina edilecek şekilde uygulanacaktır. Kıyı devletleri, boğazlardan veya üzerlerinden geçen transit trafikçe kullanılacak uygun kanalları ve koridorları belirler. Transit ve uçuşun zararsiz geçişin hükümleriyle düzenleneceği boğazlar şunlardir:

(1) Altı mil genişlikten fazla olmayan;

(2) Aynı devletin klyıları arasında konumlanan ve

(3)Boğazlarla bă̆lı deniz klsımları arasında diğer iletişim güzergâhlarına yakın olan."

\footnotetext{
${ }^{48}$ Bkz. "Straits ...", vol. I, s. 89.

${ }^{49}$ Bkz. "Straits ...", vol. I, s. 103-104.

50 "(a) Subject to the provisions of paragraph (b), all ships and all aircraft shall enjoy, for the purposes of transit through or over straits connecting two parts of the high seas or
} 
İtalya sunmuş olduğu boğazlara ilişkin taslak maddelerin içeriğini de yine aynı toplantıda delegesi aracılı̆̆ıla ortaya koymuştur. ${ }^{51} \mathrm{Bu}$ çerçevede, İtalyan delege, paragraf (a)'da ülkesinin uluslararası seyrüseferde kullanılan boğazlardan veya onların üzerinden transit serbestisi ihtiyacını teyit ettiğini belirtmiş, özellikle gelişmekte olan devletlerle birlikte, bu tür boğazlar üzerinden gerçekleşen ticaretin yıldan yıla artış gösterdiğini ve uluslararası ilişkilerin mevcut bu durumunda bu tür boğazların küçük bir azınlık teşkil eden devletlerin kontrolüne bırakılmasının yersiz olacağını vurgulamıştır. $\mathrm{Bu}$ tür bir durumdan kaçınmak için, delege, ülkesinin kıyı devletlerinin hak ve ödevlerini tanımladığını, bu çerçevede onlara transit trafik için uygun kanal ve koridorları belirleme hakkını öngörürken, öte yanda zarurî olmayan tüm engellerden imtina etmeleri ödevini yüklemiş olduğunu dile getirmiştir. Delege sözlerini, boğazların tehlikeli ve kirletici faaliyetler için kullanılmaması gerektiğini ekleyerek sürdürmüştür. Boğazlar sorunun çözümünün tüm uluslararası toplum için zarurî olduğunun altını çizerek sözlerine devam eden delege, özellikle de başka şekilde olmadıkça kapalı veya yarı-kapalı deniz durumuna gelecek denizler için sorunun önemine işaret etmiş ve örnek olarak Akdeniz'i göstermiş ve bu deniz alanının Atlantik'e tek çıkışı olduğu ve bu çıkıştan her zaman seyrüsefer serbestisinin var olduğunu, bunun da korunmasının hayatî bir önem teşkil ettiğini dile getirmiştir. Bu çerçevede, uluslararası toplumda denize kıyısı olmayan devletlerin denizlere serbestçe ulaşımının olması gerektiğinin kabûl edildiğini, bu konuda akıllara 1958 tarihli Cenevre Açık Denizler Sözleşmesi m. 3'ün getirilmesi gerektiğini ve şimdi Komitenin kapalı veya yarı-kapalı denizlere kıyısı olan çok büyük sayıda devletin çıkarlarına aykırı bir şekilde hareket etmesinin anlamsız olacağını vurgulamıştır. Delege, son olarak, (b) paragrafina ilgili açıklamalar yaparak, bu paragrafla ülkesinin transit hakkının kullanımının ancak

connecting part of the high seas with the territorial sea of a foreign State, the same freedom of navigation or overflight as exists on the high seas.

(b) The freedom of transit shall be so exercised as to avoid (all necessary) obstruction of traffic. The coastal States may designate appropriate channels and corridors to be used by transit traffic passing through or over the straits. Transit and overflight shall be governed by the provisions concerning innocent passage in straits which:

(1) Are not more than six miles wide;

(2) Lie between coasts of the same State; and

(3) Are near other routes of communication between the parts of the sea connected by the straits."

${ }^{51}$ Bkz. "Straits ...”, vol. I, s. 111-112. 
zorunluluk teşkil etmesi ve başkaca bir çözüm bulunmaması durumunda söz konusu olması gerektiğini teyit ettiğini belirtmiş ve paragrafin (1) ve (2) no'lu alt başlıklarında zararsız geçiş hakkının tarihî tecrübeyle sabit altı deniz mili aşmayan bir genişlik olarak belirlendiğini ifade etmiştir.

\section{Gerek İtalyan taslağı, gerekse bu taslağa ilişkin İtalyan delegasyonunun açıklamalarını Endonezya ${ }^{52}$ İspanya $^{53}$, Malezya ${ }^{54}$,}

\footnotetext{
${ }^{52}$ Bkz. "Straits ...", vol. I, s. 112-113. Endonezya delegesi, İtalyan önerisinin, bütün olarak açık olmadığını, kendilerinin de dâhil olduğu Sekiz Güç tarafindan sunulan öneriyle çeliştiğini ifade etmiş; Endonezya'nın, karasularının kıyı devletinin ülkesinin egemen bir parçası olarak bölünemez olduğunu ve bu itibarla da geçişe ilişkin uygulanacak rejimlerin farklı olamayacağını düşündüğünü belirtmiştir. Öte yandan, delege, zararsız geçiş rejiminin altı deniz milinden geniş olmayan boğazlarda uygulanmasına ilişkin öneriye karasularının genişliğinin üç değil, 12 deniz mili olduğunu düşündüğü için katılmadığının altını çizmiştir. Önerinin (b) paragrafında ise, üç koşulun birlikte mi yoksa tek tek mi ele alınacağının anlaşılamadığına işaret etmiştir. Ayrıca, trafiğe ilişkin zarurî olmayan tüm engellerden kaçınılması gerektiği gibi bir ibareye yer verildiğinin, buna karşılık kıyı devletlerinin güvenliğinden dem vurulmadığının, ilâve olarak bu engelin varlığının kimin tarafından belirleneceğinin açıklanmadığının altını çizmiştir. Endonezya'nın görüşü, bu çerçevede, bu türlü bir belirlemenin kıyı devletince yapılması şeklindedir. Endonezya delegesi, aynı zamanda, kendi takımada sularının Hint ve Pasifik Okyanusları arasında bulunmasından ötürü, iki açık deniz kesimini bağladıkları şeklinde değerlendirilip değerlendirilemeyeceği konusunda emin olamadıklarını, böyle bir konseptin ulusal birliğine siyasî etkileri ve güvenlik gibi nedenlerle Endonezya için kabûl edilemez olduğunu belirterek, İtalyan delegesinin takımada sularına ilişkin bir garanti vermesini istemiştir.

${ }^{53}$ Bkz. "Straits ...", vol. I, s. 113-114. İspanyol delegesi, İtalyan önerisine ilişkin, öncelikle, seçilen altı deniz millik genişlik çerçevesinde duyduğu şaşkınlığı dile getirmiş, İtalya'nın da tıpkı kendileri gibi altı deniz millik karasuları genişliğini benimsediğini belirtmiştir. Dahası, Uluslararası Hukuk Komisyonunun 1956 yılında aldığı karar çerçevesinde İtalya'nın 24 deniz mili genişliği benimsemesinin daha mantıklı olabileceğinin altını çizmiştir. Delege, değerlendirmelerinin devamında, (b) paragrafının ikinci kriterini teşkil eden aynı devletin kıyıları arasında kalan boğazlardan ne anlaşılması gerektiğinin açık olmadığı, kabûl edilen uluslararası hukuk doktrinine göre zararsız geçiş hakkının olduğu boğazların uluslararası seyrüseferde kullanılan ve iki açık deniz alanını birbirine bağlayan boğazlar olduğunu dile getirmiştir. Uçuş hakkına gelince, İtalyan delegesinin bu öneriden çok önce yaptığı konuşmada da beyan ettiği gibi bu konunun II. Komitenin yetkisine girmediğini belirten İspanyol delegesi, uçuş hakkının zararsız geçiş rejiminin hiçbir zaman bir parçası olmadığının da altını çizmiştir. Sonuç olarak, İspanya, İtalyan önerisinin boğazlardaki seyrüsefer için tatmin edici bir temel teşkil etmediğini belirtmiştir. Öte yandan, belirtilmelidir ki, öneriye ilişkin değerlendirmelerden sonra, önerinin açıklanmasına ilişkin İtalyan delegenin gerçekleştirdiği konuşma esnasında Cebelitarık örneğine ilişkin de, İspanya, serbest transit rejiminin söz konusu olduğu iddiasına ise şiddetle karşı çıkmıştır.
} 
$\mathrm{SSCB}^{55}$ ve Amerika Birleşik Devletleri ${ }^{56}$ değerlendirmiş; bu değerlendirmelere ilişkin İtalyan delegesi ise $\operatorname{cevap}^{57}$ vermiştir. İtalyan delegesinin cevabına değinmeden evvel belirtilmelidir ki, Endonezya, İspanya ve Malezya İtalyan'ın önerisini ciddî biçimde eleştirirken, boğazlar konusunda işbirliği yapan iki süper güç ise öneriye gayet olumlu yaklaşmışlardır. $^{58}$ İtalyan'ın teklifine yönelik diğer devletlerin

${ }^{54}$ Bkz. "Straits ...", vol. I, s. 115-117. Malezya delegesi ise, altı mil genişlikten daha fazla olmayan boğazlarda zararsız geçiş rejiminin söz konusu edilmesine şaşırdığını ifade ederek, kıyı devletinin karasularında kıyı devletine getirilen bir servitüt olarak kabûl edilecek zararsız geçiş ilkesinin getirilen öneriyle birlikte o devletin hava sahasında da uygulanacağı anlamına gelip gelmediğini sorgulamıştır. Karasuları genişliğinin 12 deniz milde sabit kılınmasını savunan delege, İtalya'nın ise altı deniz milini seçtiğini, bunun da özel bir durumu kast ettiğine kani olduklarını belirterek, ilgili önerinin uluslararası seyrüsefer rejimi için kullanılamayacağını belirtmiş ve ülkesinin bu öneriye çekince koyduğunu ifade etmiş̧tir.

55 Bkz. "Straits ...", vol. I, s. 117-120, özellikle s. 119. SSCB delegesi, diğer delegasyonlarca boğazlara dair İtalyan önerisine karş1 gerçekleştirilen eleştirilerle aynı fikirde olmadıklarını, öneriyi değerlendiren delegasyonların yapıcı bir yaklaşımdan uzak olduğunu belirtmiş, önerinin bir bütün olarak değerlendirildiğinde, temel olarak, uluslararası boğazlardan serbest geçiş ilkesini tanıdığının görüldüğünü belirtmiştir. Boğazlardan serbest geçiş ilkesini tanımamanın, dünyanın 130'a yakın devletine ait gemilerinin bu boğazlardan geçişini boğazlara bitişik 12 ilâ 15 arasında bir devletin hâkimiyetine tâbi kılma isteğinin açık bir göstergesi olduğunu ifade etmiştir. Bununla birlikte, İtalyan önerisinin katılmadıkları kısımlarının olduğunu da belirten delege, bunları şu şekilde saymıştır: açık deniz ile karasularını birbirine bağlayan boğazlarda serbest geçiş rejiminin tanınması, (b) paragrafında belirtilen altı millik genişlik.

${ }^{56}$ Bkz. "Straits ...", vol. I, s. 122. Amerika Birleşik Devletleri delegesi, ülkesinin İtalyan'ın çözüm amaçlı önerisini takdir ettiğini ve üzerinde çok dikkatli bir şekilde çalışılacağını belirtmiştir.

${ }^{57}$ Bkz. "Straits ...", vol. I, s.127-129.

${ }^{58}$ Esasen iki süper gücün olumlu tavır takınmalarını yadırgamamak gereklidir. Özellikle, 1970'lerin başında karasuları genişliğinin arttırılması eğilimi karşısında boğazlardaki serbest geçişi koruma amaçlı iki süper güç, bu konu çerçevesinde beraberce hareket etmeye başlamışlardır. Konuya ilişkin daha ayrıntılı değerlendirmeler için bkz. GHOSH S., Superpower Co-Operation and Transit Passage through Straits, Economic \& Political Weekly, vol. 20/18, 1985, s. 808-810; SANGER, s. 20-21. İtalyan hukukçu Giuliano konuyu iki süper güç ekseninden değil, daha geniş bir çerçeveden ele almış; başta denizci devletler olmak üzere bir grup devletin, özellikle artan 12 deniz millik karasuları genişliğinin seyrüsefer üzerindeki negatif etkisinden endişe duyduklarını, başta boğazlara kıyısı olan diğer bir grup devletin ise boğazlardan çok geniş biçimde sağlanacak geçiş özgürlüğünün belirli durumlarda güvenlikleri için potansiyel tehlike teşkil edeceği ve deniz çevresinin olumsuz yönde etkilenebilecek olması şeklindeki iki temel unsurdan etkileneceklerini belirterek, müzakerelerin bu çerçevede süreceğini dile getirmiştir. Bu bağlamda, yazar, ayrıca İtalya'nın, yukarıda belirttiğimiz önerisine de değinerek ilk grupta yer aldığına işaret etmiştir. Bkz. GIULIANO M., The Regime of 
değerlendirmelerine İtalya'nın verdiği cevaba gelindiğinde, özet olarak, önerilen taslağın iki temel bölümden oluştuğunun, ilkinin boğazlarda seyrüseferi veya uçuşu yöneten temel ilkelerin, yâni transit serbestisinin altını çizdiğinin ki, bunun da deniz ve hava trafiğinin sevkine dair teknik nitelikli sadece tek bir sınırlandırmaya tâbi kılındığının; ikincisinin ise altı deniz milini aşmayan genişlik, kıyılarının aynı devlete ait olması ve bu boğazla bağlanan ilgili deniz kısımları arasında başka bağlantı güzergâhlarının da olması şeklinde sayılan genel ilkelere getirilmiş istisnaları içerdiğinin belirtildiği görülmektedir. Delege cevabın devamında, İtalya'nın daha önce uçuşa ilişkin konuların başka uluslararası belgelerde düzenlenmesinden ötürü bu konunun Alt Komitenin yetki alanına girmediğini belirttiğini, buna karşllık bu görüşün ihrazî nitelikte bir görüş olduğu ve resmî İtalyan görüşünü yansıtmayabileceğini ki, aynı konuşmada İtalya'nın görüşülmesi istenilen konularda geri adım atılmaması gerektiğini vurguladığını da ifade etmiş ve zaten komitenin konuyu gündemine aldığına işaret etmiştir. Delege, İtalya'nın, boğazlar konusunun çözülebilmesinde temsil edilen çeşitli çıkarlar arasında hakça bir uzlaşının sağlanması gerektiğine inandığını vurgulayarak, kıyı devletlerinin çıkarlarının uluslararası toplumun çıkarlarını yok etmeksizin diğerlerininkiyle koordine edilmesi gerektiğini belirtmiştir. Cevabın ilerleyen kesimlerinde denizcilik tarihinin kıyı devletlerinin boğazları kontrolünün daha ileri geçiş serbestilerine yol açtığını gösterdiğini belirtmiş ve örnek olarak Danimarka Boğazlarıyla Cebelitarık Boğazını vermiştir. Delege, böylelikle, ülkesinin önerisinin uluslararası toplumun çıkarlarıyla uyumlu olduğunu dile getirmiş ve hiçbir şekilde ne genel olarak ne de kapalı denizlere giriş özel durumuna bağlı olarak 1958 tarihli Cenevre Sözleşmesi düzenine aykırılık içermediğini vurgulamıştır. Bunlar bağlamında, delege, boğazlardan serbest geçişe ilişkin daha yoğun düzenlemelere karşı çıkışın iki temel dayanağı olduğunu; ilkinin gerek antlaşmaların gerek beyanların izafî bir karakterde olduğu ve üçüncü devletlerin serbest geçiş ilkesinin tam tanınması anlamına gelmediği, ikincisinin ise bu belgelerin boğazları ele alışının talî biçimdedir iddiası olduğunu belirtmiştir. $\mathrm{Bu}$ iddialara karşı ise, delege tüm devletlerin o antlaşmaların lafzı ve ruhuna dayanarak boğazlardan geçiş hakkını kullandığ1 ve geçiş rejiminin tüm o antlaşmaların temel düzenleme hususunu teşkil ettiğini vurgulamıştır. Daha sonra, tekrar ülkesinin öneri

Straits in General International Law, Italian Yearbook of International Law, vol. 1, 1975, s. 24-26. 
metnine dönerek (b) paragrafinda ulusal boğaz olarak nitelendirilebilecek boğazlara ilişkin sıralanan üç koşulun bir bütün olarak ele alınması gerektiğini aktararak, kendi ülkesi dâhil birçok devletin altı deniz milinden daha geniş karasuları genişliği benimsediğinin bilincinde olduklarını ama getirdikleri öneride bu sayının seçilmesinin sebebinin tüm bu yönlü karşı çıkışların önüne geçmek olduğunu ifade etmiştir. Üçüncü koşul ise, delege tarafından, kıyı devletlerinin tek geçiş teşkil etmeyen boğazları üzerindeki çıkarlarının reddedilmemesi olarak savunmuştur. Bunun haricinde, "kazanılmış hak" gibi bir ibareye yer verilmesinden kaçınmanın sebebini ise, bu ibarenin oldukça farklı yorumları olmasına, bilimsel konularla bağlantıda oldukça çelişir bir durum yaratmasına ve uluslararası hukuk çerçevesinde betimlenmesinin güçlügüne dayandırmıştır. Son olarak, İtalya'nın ilgili bu önerisine ilişkin bir öz eleştiri yapan delege, her ne kadar (a) paragrafında dile getirilen ilkenin herkes için kabûl edilebilir olmasına karşılık, (b) paragrafındaki düzenlemenin daha fazla açıklamaya ihtiyaç gösterdiğini de kabûl etmiştir.

İtalya'nın bu önerisinden etkilenen Birleşik Krallık II. toplantıya sunduğu ve daha sonradan kendisiyle Fiji'nin ortak olarak sunacakları ve 1982 Birleşmiş Milletler Deniz Hukuku Sözleşmesinin III. bölümünün temelini teşkil edecek taslağ düzenlemeye yer vermiştir" "(4) Transit geçiş, bir boğazda sadece şu bağlamda uygulanacaktır: ... (b) Ĕger boğaz kiyı devletinin bir adasınca oluşturulmuşsa, adanın deniz tarafinda aynı oranda uygun bir açık deniz geçişinin olmaması". Bu öneri dişında da, benzer taslak önerilerinin olduğu gözden kaçırılmamalıdır. ${ }^{60}$ Nihayetinde, bu düzenlemeler 1982 Birleşmiş Milletler Deniz Hukuku Sözleşmesi m. 38/1 olarak karşımıza çıkmıştır. ${ }^{61}$

${ }^{59}$ Bkz. "Straits Used for International Navigation-Legislative History of Part III of the United Nations Convention on the Law of the Sea", volume II, United Nations: Division for Ocean Affairs and the Law of the Sea Office of Legal Affairs, New York, 1992, s. 15. (Bundan sonra "Straits ...", vol. II)

${ }^{60}$ Danimarka ve Finlandiya tarafindan sunulan ortak değişiklik önergesi m. 1/4 (b) aynen şu şekildedir: "4. Transit geçiş bir boğazda ancak şu bağlamda uygulanacaktır:

...

Ĕger boğaz kıyı devletinin bir adasıyla oluşturulmuşsa, adanın deniz tarafinda eşit uygunlukta bir açık deniz geçişinin var olmadiğında". Bkz. "Straits ...", vol. II, s. 21.

${ }^{61} 1982$ Birleşmiş Milletler Deniz Hukuku Sözleşmesi m. 38/1 şu şekildedir: “Madde 37’de belirtilen boğazlarda, tüm gemi ve uçaklar, herhangi bir engelleme olmaksızın transit hakkından yararlanır; ancak, boğaz, kıyıdaş devletin adası ve anakarası arasında 
III. Deniz Hukuku Konferansının Caracas'ta 20 Haziran ilâ 29 Ağustos 1974 tarihinde gerçekleştirilen II. Oturumunda İtalyan delege, uluslararası boğazlardan engellenmeden geçişin teyit edilmesi, temelde ulusal önemi haiz boğazlarda ise zararsız geçiş hakkının devam ettirilmesi gerektiği görüşünde olduklarını paylaşmıştır. ${ }^{62}$ II. Komitenin 4 numaralı ajandasını teşkil eden boğazlar konusu tartışılırken, İtalyan delegesi ülkesinin pozisyonun yukarıda da belirtilen teklifte ortaya konulduğunu belirterek, yine yukarıda ilgili kısmına kısaca yer verilen İngiltere'nin önerisinin de boğazlar sorununun anlaşılmasını kolaylaştırmak açısından ilginç olduğunu vurgulamıştır. ${ }^{63}$ Boğazlar konusunda, 1974 sonrası genelde oluşturulan müzakere metni üzerinden görüşmeler gerçekleştirilmiş ve birkaç ufak değişiklik harici çok büyük tartışmalar yaşanmamış görünmektedir. Bu itibarla, 1979'daki 8. Oturumda, İtalyan delegesi, Bulgar delegesiyle birlikte boğazlardan transit geçişe dair müzakere metninden ülkesinin duyduğu tatmini dile getirmiştir. ${ }^{64}$ Son olarak belirtilmelidir ki, 11. Oturumun ilk kısmında İspanya ve her ne kadar sonradan önerisini geri çekse de Yunanistan birtakım öneriler getirmişlerdir. ${ }^{65} 11$. Oturumun ikinci kısmında ise, bu önerilere ilişkin oylamaya geçilmeden evvel delegeler görüş bildirmiş, bunlardan İtalyan delege seyrüsefer ve uçuş hakkına ilişkin kısımlar tekrardan formüle edilmeye kalkarsa, başta Amerika Birleşik Devletleri olmak üzere bazı denizci güçlerin Sözleşmeyi imzalamayacağı uyarısında bulunmuştur. ${ }^{66}$

İtalya'nın, III. Deniz Hukuku Konferansı esnasında delegeleri aracılığıyla aktardığı boğazlara ilişkin görüşleri bir yana, deniz hukukunun ana hatları çerçevesindeki konumunu da kısaca özetlemek yerinde olacaktır. İtalya, 1982 tarihli Birleşmiş Milletler Deniz Hukuku Sözleşmesi öncesinde gerçekleştirilen dört Cenevre Sözleşmesinden

oluşmuşsa, ĕger adanın deniz tarafinda benzer nitelikli seyrüsefersel ve hidrografik özellikleri gösteren açık deniz veya münhasır ekonomik bölgeden geçen bir güzergâhın olması durumunda uygulanmayacaktır". Bu maddenin tarihçesine ilişkin bir değerlendirme için bkz. NANDAN S.N. \& ANDERSON D.H., Straits Used for International Navigation: A Commentary on Part III of the United Nations Convention on the Law of the Sea 1982, British Yearbook of International Law, vol. 60, 1989, s. 179-181.

${ }^{62}$ Bkz. "Straits ...", vol. II, s. 14.

${ }^{63}$ Bkz. "Straits ...", vol. II, s. 46.

${ }^{64}$ Bkz. "Straits ...", vol. II, s. 119.

${ }^{65} \mathrm{Bu}$ önerilere ilişkin bkz. "Straits ...”, vol. II, s. 134-135.

${ }^{66}$ Bkz. "Straits ...", vol. II, s. 137. 
sadece ikisine taraftır. ${ }^{67}$ İtalya, 1982 tarihli Birleşmiş Milletler Deniz Hukuku Sözleşmesi'ne ise, 10 Aralık 1982 tarihinde imza atmışken, 13 Ocak 1995 tarihinde onaylayarak tarafı hâline gelmiştir. ${ }^{68}$ İtalya'nın esas hatları 1977 tarihli bir kararnâme ile belirlenmiştir. Bu kararnâmede ortaya konulduğu üzere, Toskano Takımadalarının en uç noktaları esas hatlar için temel alınmış, Taranto Körfezi ise tarihsel körfez iddiasıyla ağzına çizilen bir kapatma hattıyla kapatılmıştır. Taranto Körfezine ilişkin bu iddia protestolarla karşılaşmışıır. ${ }^{69}$ Öte yandan, Malta da İtalya'nın Sicilya'nın güneyinde çizdiği bazı esas hatları tanımayacağını belirtmiştir. ${ }^{70}$ İtalya, 12 deniz mili karasuları genişliğini ise, 24 Ağustos 1974 tarih ve 359 sayılı Kanun ile benimsemiştir. ${ }^{71}$ Öte yandan, İtalya, 8

67 İtalya 17 Aralık 1964 tarihinde 1958 tarihli Cenevre Karasuları ve Bitişik Bölge Sözleşmesine ve 1958 tarihli Cenevre Açık Denizler Sözleşmesine katılmıştır. Sırasıyla, bkz. via https://treaties.un.org/pages/ViewDetails.aspx?src=TREATY\&mtdsg_no=XXI$1 \&$ chapter=21\&clang=_en (son ziyaret tarihi: 20/09/16) ve via https://treaties.un.org/pages/ViewDetails.aspx?src=TREATY\&mtdsg_no=XXI-

2\&chapter=21\&clang=_en (son ziyaret tarihi: 20/09/16). Öte yandan, İtalya, diğer iki sözleşme olan 1958 tarihli Cenevre Balıkçılık ve Açık Denizlerdeki Canlı Kaynakların Korunması Sözleşmesi ile 1958 tarihli Cenevre Kıta Sahanlığı Sözleşmelerine ise taraf değildir. Bkz.

https://treaties.un.org/pages/ViewDetails.aspx?src=TREATY\&mtdsg_no=XXI-

$3 \&$ chapter=21\&clang=_en (son ziyaret tarihi: 20/09/16) ve via https://treaties.un.org/pages/ViewDetails.aspx?src=TREATY\&mtdsg_no=XXI4\&chapter=21\&clang=_en (son ziyaret tarihi: 20/09/16).

${ }^{68}$ Birçok batılı devlet gibi İtalya'nın da 1982 tarihli Birleşmiş Milletler Deniz Hukuku Sözleşmesini imzalamaya karar vermesi 1994 tarihli XI. Bölümün Uygulanmasına Dair Anlaşmadan sonra olmuştur. Bu itibarla, İtalya, adı geçen 1994 tarihli Anlaşmayı da 29 Temmuz 1994 tarihinde imzalamış ve 1982 Sözleşmesiyle birlikte aynı tarihte onaylamıştır. Bkz. TREVES, 1997, s. 327.

${ }^{69}$ Taranto Körfezine dair en ciddî protesto Amerika Birleşik Devletleri'nden gelmiştir. Bkz. ROACH J.A. \& SMITH R.W., Excessive Maritime Claims, 3rd edition, Martinus Nijhoff Publishers, Leiden, 2012, s. 44-45. Taranto Körfezine ilişkin doktrinde yaşanan görüş alışverişine dair bkz. RONZITTI N., Is the Gulf of Taranto an Historic Bay?, Syracuse Journal of International Law \& Commerce, vol. 11/2\&3, 1984, s. 275-296; RONZITTI N., New Criticism on the Gulf of Taranto Closing Line: A Restatement of a Different View, Syracuse Journal of International Law \& Commerce, vol. 12/3, 1986, s. 465-472; WESTERMAN G., The Juridical Status of the Gulf of Taranto: A Brief Reply, Syracuse Journal of International Law \& Commerce, vol. 11/2\&3, 1984, s. 297-309.

${ }^{70}$ Bkz. TREVES, 1997, s. 328.

7130 Mart 1942 tarihli Seyrüsefer Kanununa değişiklik getiren 24 Ağustos 1974 tarih ve 359 sayılı Kanunun Karasuları başlığını taşıyan 2 no'lu maddesinin ikinci paragrafında İtalyan Devletinin karasuları genişliğini 12 deniz miline çıkarttığı görülmektedir. İlgili düzenlemeye ilişkin

bkz.

via 
Şubat 2006 tarihli ve 61 sayılı Kanun $^{72}$ ile bir Başkanlık Kararnâmesiyle karasularının dış sınırından başlayan bir "ekolojik koruma bölgesi" (ecological protection zone) oluşturulmasını öngören düzenlemeyi kabûl etmiş ve bu bölgenin sınırlarını ve içeriğini tespit eden 27 Ekim 2011 tarih ve 209 sayılı Başkanlık Kararnâmesiyle ${ }^{73}$ bu bölgeyi hayata geçirmiştir. ${ }^{74}$

\section{V. İtalya'nın Boğazlarının Hukukî Rejimi}

Tüm bu anlatılar sonrasında, İtalya'nın en azından bir kıyısında konumlandığı boğazların hukukî rejiminin değerlendirilmesine geçilebilir. İtalya'nın boğazları değerlendirildiğinde, en azından ele alınanlar bağlamında, hepsinin uluslararası niteliği haiz boğazlar olduğu gözlenmektedir. Yâni, bunlar, yukarıda belirtildiği ve 1982 tarihli Birleşmiş Milletler Deniz Hukuku Sözleşmesinde öngörüldüğü şekilde deniz alanlarını birbirine bağlayan ve uluslararası seyrüseferde kullanılan boğazlardır.

İtalya'ya ait en önemli boğazlardan biri, yukarıda III Deniz Hukuku Konferansı süresince İtalyan delegasyonun yoğun çabalarıyla oluşturulan

www.un.org/Depts/los/LEGISLATIONANDTREATIES/PDFFILES/ITA_1974-

Code.pdf (son ziyaret tarihi: 19/09/16). Esasen, İtalya, üç deniz millik karasuları genişliğini uygulayan bir devlet değildir. 1942 tarihli Seyrüsefer Kanunun 2. maddesiyle altı deniz millik karasuları genişliği belirlenmiştir. 1970'lerin başında İtalya henüz karasuları genişliğini 12 deniz miline çıkartmamışken konuyu değerlendiren İtalyan hukukçu Durante, üç deniz millik genişliğin yeterli olmadığından dem vurmuş, zaten altı deniz mili genişliği kullanan İtalya'nın yakın bir tarihte karasuları genişliğini 12 deniz miline çıkartmasının bekleneceğini ifade ederek (yazar, o dönem birçok devletçe karasuları için belirlemiş oldukları aşkın genişliklerin ise tasvip edilmeyeceğinin altını çizmiştir), buna ilişkin örnek olarak İtalya'nın uzun bir zamandır gümrük çerçevesinde 12 deniz millik bir genişliği benimsemesini göstermiştir. Bkz. DURANTE F., Italy, in New Directions in the Law of the Sea, vol. III, edited by Churchill \& Simmonds \& Welch, , London, 1973, s. 266-267.

${ }^{72}$ İlgili bu kanun İngilizce metni için bkz. via www.un.org/Depts/los/LEGISLATIONANDTREATIES/PDFFILES/ITA_2006_Law.pd f (son ziyaret tarihi: 19/09/16).

${ }^{73}$ İlgili bu kararnâmenin İngilizce metni için bkz. via www.un.org/Depts/los/LEGISLATIONANDTREATIES/PDFFILES/ITA_2011_Decree. pdf (son ziyaret tarihi: 19/09/16).

${ }^{74}$ İtalya'nın ekolojik koruma bölgesine ilişkin değerlendirmeler için bkz. GRBEC M., Extension of Coastal State Jurisdiction in Enclosed and Semi-Enclosed Seas: A Mediterranean and Adriatic Perspective, Routledge, Oxon, 2014, s. 94-101; TREVES T. \& PAPANICOLOPULU I., The Law Applicable on the Continental Shelf and in the Exclusive Economic Zone: The Italian Perspective, Ocean Yearbook, vol. 25, 2011, s. 351-352. 
ve ilgili boğazın adıyla anılan bir istisna hâline gelen Messina Boğazıdır. ${ }^{75}$ Bu bağlamda, Messina Boğazı, 1982 tarihli Birleşmiş Milletler Deniz Hukuku Sözleşmesi m. 38/1 çerçevesinde askıya alınamayan zararsız geçiş hakkının söz konusu olduğu bir boğazdır. ${ }^{76}$ Buna karşılık, İtalyan Hükûmeti 1985 tarihinde yayımladığı ardışık iki kararnâmeyle, çevre sorunları bağlamında hareket ederek, bu hakkı dahi kısıtlamıştır. ${ }^{77}$ Yaşanan bir tanker kazasına ${ }^{78}$ bağlı olarak gerçekleştirilen bu tek taraflı hukuk işlemini Amerika Birleşik Devletleri ciddî şekilde protesto etmiştir. ${ }^{79}$ İtalya'nın bugün dahi geçerli olan ve kararnâmelerle getirmiş olduğu bu düzenlemeleri şu şeklinde özetlenebilir:

- Tüm ticaret gemileri Messina Boğazında belirlenmiş olan trafik ayrım şemalarının sağını kullanacaktır;

- Tüm ticaret gemileri Messina Boğaz bölgesine giriş yapmadan evvel Messina ve Reggio di Calabria'daki denizcilik yetkililerine raporlandıracaktır;

- 6000 tonun üzerindeki tanker ve deniz çevresine zararlı madde taşıyan gemilerle, her hâlükârda 15000 tonun üzerindeki tüm gemiler için zorunlu pilotaj öngörülmüştür;

- 50000 tonun üzerindeki tüm petrol tankerleriyle deniz çevresine zararlı olan yük taşıyan tüm gemilerin Messina Boğazını kullanımı yasaklanmıştır.

${ }^{75} \mathrm{Bu}$ konuda farklı görüşleri de ....

${ }^{76}$ Tespit edilebildiği kadarıla ve katılmadığımız üzere, en azından bir yazar, Messina Boğazında transit geçiş rejiminin söz konusu olduğunu belirtmiştir. Bkz. AHNISH F.A., The International Law of Maritime Boundaries and the Practice of States in the Mediterranean, Oxford University Press, Oxford, 1993, s. 286.

${ }^{77}$ Boğazlarla ilgili seyrüsefer konularının bu denli tartışılmadığı bir dönemde, I. Dünya Savaşı esnasında, İtalya, savaşa dâhil olmadığı müddetçe, tarafsızlık kurallarını neden göstererek, Messina Boğazını tüm devletlerin savaş gemilerine kapatmıştır. Bkz. TRUVER, s. 156.

${ }^{78}$ Bkz. GESTRI M., The Legal Regime of Navigation through the Strait of Messina, Marine Pollution Bulletin, vol. 19/8, 1988, s. 354; SCOVAZZI T., The Strait of Messina and the Present Regime of International Straits, in Navigating Straits: Challenges for International Law, edited by Caron \& Oral, Brill Nijhoff, Leiden, 2014, s. 146.

${ }^{79}$ Amerika Birleşik Devletleri protestosunun metni ve İtalya'nın cevabı için bkz. ROACH \& SMITH, s. 308-310. Ayrica, bkz. MOLENAAR J., Navigational Rights and Freedoms in a European Regional Context, in Navigational Rights and Freedoms and the New Law of the Sea, edited by Rothwell \& Bateman, Martinus Nijhoff Publishers, Dordrecht, 2000, s. 37-38; SCOVAZZI, 2014, s. 147-148. 
Belirtildiği üzere, askıya alınamayan zararsız geçiş hakkının söz konusu olduğu Messina Boğazı için öngörülen bu tek taraflı önlemler, belirli gemiler için geçiş, askıya alınma bir yana, Amerikan protestosunda da ifade olunduğu üzere, tamamen kaldırılmıştır. ${ }^{80}$ Bunun, mevcut uluslararası deniz hukuk kurallarıyla bağdaşmadığı aşikârdır. Nitekim, İtalyan hukukçular dahi İtalya'nın bu düzenlemelerini eleştirmektedir. ${ }^{81}$ Buna karşılık, meselâ Scovazzi her ne kadar İtalya'nın bu düzenlemelerinin mevcut uluslararası deniz hukuku kurallarıyla bağdaşmadığını ifade etmiş olsa da, mevcut düzenlemelerin, özellikle çevre konularında kıyı devletleri için ciddî eksiklikleri olduğuna işaret ederek, bu düzenlemelerin mâkul olarak nitelendirilebileceğini, hattâ uluslararası hukuk çerçevesinde "zaruret hâline" (state of necessity) dayandırılabileceğini dile getirmiştir. ${ }^{82}$ Messina Boğazına ilişkin bir parantez açarak, adı geçen bu boğazda uzun soluklu bir köprü projesinin olduğu ve hayata geçirilebileceği de belirtilmelidir. ${ }^{83}$

Fransa'ya ait Korsika Adası ile İtalya'ya ait Sardunya Adası arasında konumlanan Bonifacio Boğazı, kıyıdaşı iki devlet arasında birtakım antlaşmaların konusunu oluşturmuştur. Bu boğaz alanına ilişkin ilk önemli antlaşmalardan biri sayılabilecek 1908 tarihli boğazdaki balıkçılık alanların sınırlandırıldığı antlaşmayı, bu antlaşma üzerine inşa edildiği ifade olunabilecek karasularının sınırlandırmasını içeren ve aşağıda kısaca ele alınacak 1986 tarihli sınırlandırma antlaşması izlemiştir. Esasen, Treves, bu ikinci antlaşmanın, seyrüseferle ilgisi yokmuş gibi olsa da, seyrüsefer temelindeki düşüncelerle gerçekleştirildiğini belirtmiş ve bunu iki devletin savaş gemilerinin boğazdan diğerinin ülkesel alanını ihlâl etmeksizin daha rahat geçebilmesi için gerçekleştirildiği şeklinde izah etmiştir. ${ }^{84}$ Çevre konularında baskılar

${ }^{80}$ Molenaar ise, Amerika Birleşik Devletleri protestosunun, sadece, belirli gemilerin geçişinin boğazda engellenmesiyle sınırlı olduğunun, oysa bu yasağın kıyı devletinin karasularındaki geçişi düzenleme yetkisiyle de uyumsuz olduğunun altını çizmiştir. Bkz. MOLENAAR, s. 38.

${ }^{81}$ Bkz. GESTRI, s. 355; SCOVAZZI, 2014, s. 148. Treves ise, konuya dair ilginç bir noktayı vurgulamıştır. 1988 yılında Endonezya'nın silâhlı tatbikat da dâhil askerî manevra gerekçesiyle kısa süreliğine Sunda ve Lombok Boğazlarını kapatmasına karşıllık İtalya'nın, İspanya ile birlikte, Avrupa Birliği üyesi devletler adına Endonezya'yı kınadığına işaret etmiştir. Bkz. TREVES, 1997, s. 336.

${ }^{82}$ Bkz. SCOVAZZI, 2014, s. 148-149.

${ }^{83}$ Konuya ilişkin değerlendirmeler için bkz. CAMINOS \& COGLIATI-BANTZ, s. 340341; SPADI, 411-419. Ayrica, bkz. SCOVAZZI, 2014, s. 149.

${ }^{84}$ Bkz. TREVES, 1994, s. 122. 
sonrası, kıyıdaş iki devletin uluslararası bir antlaşma yapmadan ${ }^{85}$ tamamen iç düzenlemelerle belirli gemilerin geçişini düzenledikleri gözlenmektedir. Bu itibarla, İtalya ve Fransa 1993 yılında yayınladıkları iki ayrı, fakat simultane kararnâme ${ }^{86}$ aracılığılyla kendi bayraklarını ${ }^{87}$ taşıyan tanker, gaz veya kimyasal taşıyıcılarla, yük olarak petrol ve kimyasal ürünlerle deniz çevresine zararlı ve tehlikeli diğer kirletenleri taşıyan her türlü geminin ${ }^{88}$ geçişini yasaklamışlardır. ${ }^{89}$ Hemen belirtilmelidir ki, İtalyan Kararnâmesinde İtalyan bayrağı taşıyıp da yasaklanan gemilerin bu niteliklerinin İtalya'da yürürlüğü olan uluslararası sözleşmelerde belirtilmiş olması şartı getirilmiştir. Bonifacio Boğazındaki bu düzenlemeleri değerlendiren Treves, bu düzenlemedeki unsurlara dikkat çekerek Messina Boğazında izlenilen yöntemden farklı olarak Bonifacio Boğazında uluslararası hukuka daha uygun bir yöntemin takip edildiğini mütalâa etmiştir. ${ }^{90}$ Bununla birlikte, İtalya ve Fransa'nın isteği üzerine, adı geçen boğazdaki seyrüsefere ilişkin olarak, Uluslararası Denizcilik Örgütü, aynı yıl A 766 (18) sayılı kararı kabûl etmiştir. ${ }^{91} \mathrm{Bu}$ kararda, gerek iki devletin ilgili boğaz alanındaki hassas çevre dokusunu

${ }^{85}$ Treves, gerek İtalya'nın, gerek Fransa'nın çevreye ilişkin bu duyarlı konudaki önlemleri bir an önce uygulayabilmek ve uzun ve meşakkatli müzakere süreçlerine girmemek adına, bunları iç düzenleme ile belirleme yoluna gitmeyi tercih ettiklerini belirtmiştir. Bkz. TREVES, 1993, s. 123.

${ }^{86}$ Fransız Kararnâmesinin 4. maddesi bir karşılıklılık kuralı getirmiştir ve aynen şu şekildedir: "Bu kararnâme, aynı nitelikteki ölçütleri ortaya koyan metnin İtalyan yetkililerince yayımlandı ğ tarihte yürürlük kazanacaktır".

${ }^{87}$ Fransız Kararnâmesi, sadece Fransız bayrağı taşıyan gemileri değil, aynı zamanda 2. maddeyle Fransız limanları arasında kabotaj hakkını kullanan ilgili tür tüm gemileri kapsam altına almıştır. Fransa'nın İtalya'dan farklı olarak aynı konuyu düzenleyen bu kararnâmesindeki bu hükme Treves de dikkat çekmektedir. Bkz. TREVES, 1993, s. 125; TREVES, 1997, s. 336.

${ }^{88}$ Fransız Kararnâmesi bir ayrıma daha giderek, 4. maddesinde, açık bir biçimde, başta savaş gemileri olmak üzere, ticarî faaliyette kullanılmayan hiçbir Fransız devlet gemisinin bu kurallara tâbi olmayacağını düzenlemiş̧tir.

${ }_{89} 1993$ tarihli ilgili İtalyan Kararnâmesinin 1. maddesi. Bununla birlikte, Fransız Kararnâmesinin 1. maddesi bir eke atıf yapmak suretiyle yasaklanan vasitalar bakımından daha dar bir düzenleme öngörmüştür. Bu çerçevede, petrol ve tehlikeli madde taşıyan gemiler terimi kullanılarak, örnekleme açısından eke yönlendirme yapılmıştır.

${ }^{90}$ Bkz. TREVES, 1997, s. 336.

${ }^{91}$ Uluslararası Denizcilik Örgütünün Bonifacio Boğazına ilişskin adı geçen kararının metni için bkz. via http://www.imo.org/blast/blastDataHelper.asp?data_id=23312\&filename=A766(18).pdf (ziyaret tarihi: 20/09/16). 
koruma önceliği, gerekse de uluslararası statüyü haiz bir boğazdaki seyrüsefer hakkından geri adım atılmaması gibi iki hassas dengenin korunmasının önemi vurgulanarak, hükûmetlerin petrol yüklü tankerlerinin ve tehlikeli kimyasalları veya yük olarak kirlenmeye yol açacak maddeleri taşıyan gemilerinin boğazdan geçişini yasaklamaları veya en azından bu konuda onları cesaretlendirmemeleri tavsiye edilmiştir. ${ }^{92}$ Öte yandan, 2010 yılında İtalya ve Fransa Uluslararası Denizcilik Örgütü'ne başvurarak, Bonifacio Boğazı ve çevresinin "Özellikle Korunan Hassas Deniz Alanı" (Specially Protected Marine Areas) ilân edilmesini ve bunun sonucu olarak da zorunlu klavuzluk hizmetlerinin söz konusu edilmesini talep etmişler, toplantılar sırasında iki devlet bu isteklerini geri çekmiştir ki, bunun üzerine Amerika Birleşik Devletleri bir basın bildirisi yayınlamak suretiyle iki devlete de bu konuda gösterdikleri anlayıştan ötürü teşekkür etmiştir. ${ }^{93}$

Piambioni Boğazı ise, yukarıda daha öncede belirtildiği üzere, Toskana Adalar grubunun en büyük adalarından birini teşkil eden Elba Adası ile İtalyan anakarası arasında konumlanan beş deniz mili genişliğinde bir boğazdır. ${ }^{94} \mathrm{Bu}$ özelliği ile ilk bakışta Messina Boğazının statüsüne benzeyen adı geçen bu boğazın, özellikle doktrin incelendiğinde statüsünün tartışmalı olduğu gözlenmektedir. Şöyle ki, İtalyan hukukçu Scovazzi Piambioni Boğazının deniz tarafındaki kısmında açık deniz alanı değil bir başka boğaz olan Korsika Kanalının bulunduğunu ve bu alanda İtalyan ve Fransız karasularının çakıştığını, dolayısıyla m.38/1'de aranılan gemilerin serbestçe geçebileceği açık deniz veya münhasır ekonomik bölge alanının bulunmadı̆̆ını dile getirmiştir. ${ }^{95}$ Öte yandan, İspanyol hukukçu López Martín ise, Piambioni Boğazının statüsünü Messina

92 İlgili bu kararın değerlendirilmesine dair bkz. SCOVAZZI, 1995, s. 151. Bu arada, Treves, Uluslararası Denizcilik Örgütünün bu kararında yasaklama dişında "cesaretlendirmeme" ibaresinin kullanımının kararın etkinliğini zayıflattığ1 görüşündedir. Bkz. TREVES, 1993, s. 124.

${ }^{93}$ Konuya ilişkin olarak bkz. ROACH \& SMITH, s. 287-288.

${ }^{94}$ Piambioni Adasının da dâhil olduğu Toskana Takımadaları 26 Nisan 1977 tarih ve 816 sayılı Başkanlık Kararnâmesi ile belirlenen İtalyan esas hatlarıyla kapatılmıştır. Bunun anlamı, Piambioni Boğazının İtalyan iç suları hâline gelmesidir. Bu durumda, 1982 tarihli Birleşmiş Milletler Deniz Hukuku Sözleşmesi m. 35/a akıllara gelmelidir. İlgili bu düzenlemeye göre, daha önceden içsuları teşkil etmeyen fakat Sözleşmenin 7. maddesi çerçevesinde düz esas hatların kullanımıyla birlikte içsuları hâline gelen bir boğazdaki tüm içsular teşkil eden alanlar boğazlar bölümündeki düzenlemelerden etkilenmeyecektir. Bu durumda da, zaten Piambioni Boğazının statüsü değişmemektedir.

${ }^{95}$ Bkz. SCOVAZZI, 1995, s. 151. 
istisnasını teşkil eden 38. madde 1. fikrasına uyumlu olarak kabûl etmektedir. ${ }^{96}$ Bu konuda en önemli otoritelerden biri olan Alexander' in bu konudaki ayrıntılı çalışmasında, Piambioni Boğazına, Messina istisnası listesinde yer vermediği gözlenmektedir. ${ }^{97}$ Alexander'in neden bu boğaz alanını ilgili listede göstermediğine dair bir açıklamaya da rastlanmamıştır. Öte yandan, incelendiği üzere Korsika Kanalının en dar yerinde 27 deniz mili genişliği haiz olduğu belirtilmektedir. ${ }^{98}$ Dolayısıyla, boğazın en dar yerinde dahi üç deniz millik bir açık deniz veya münhasır ekonomik bölge alanı bulunmaktadır. Normal koşullarda, eğer bu alanda seyrüsefersel veya hidrografik herhangi bir engel yoksa ${ }^{99}$, Piambioni için de m. 38/1 niteliğinde boğaz olduğu iddiası gündeme getirilebilir. Bununla birlikte, Ronzitti, açık bir biçimde Toskana Adaları için kullanılan esas hat sisteminin Korsika Kanalında genişliği 24 deniz mili altına düşürdügünü ifade etmektedir. ${ }^{100} \mathrm{Bu}$ durum da, Scovazzi'nin açıklamalarında vücut bulduğu üzere Piambioni Boğazını m. 38/1 kapsamından çıkartmaktadır. Böylelikle, Piambioni Boğazında 1982 tarihli Birleşmiş Milletler Deniz Hukuku Sözleşmesi m. 8/2 uyarınca zararsız geçiş hakkı olduğu mütalâa edilebilecektir. ${ }^{101}$

Korsika Boğazı, yukarıda değinilen Scovazzi'nin ve Ronzitti'nin açıklamalarından da gözlendiği üzere, 24 deniz milinden daha az bir genişliğe sahip olması söz konusu olduğu için ve ilgili bu boğaz iki açık deniz veya münhasır ekonomik bölge alanını birbirine bağlayan uluslararası trafikte kullanılan bir boğaz olduğu için 1982 tarihli Birleşmiş Milletler Deniz Hukuku Sözleşmesi dâhilinde transit geçiş rejiminin uygulandığı bir boğaz alanıdır. Öte yandan, Uluslararası Denizcilik

${ }^{96}$ Bkz. LÓPEZ MARTÍN, s. 95 ve 203.

${ }^{97}$ Bkz. ALEXANDER, 1986, s. 206-207. Alexander'in doğrudan konuya ilişkin ilk esere yakın tarihli bir makalesinde de, aynı şekilde, Piambioni Boğazına ilgili listede yer vermediği gözlenmektedir. Bkz. ALEXANDER L.M., Exceptions to the Transit Passage Regime: Straits with Routes of "Similiar Convenience", Ocean Development \& International Law, vol. 18/4, 1987, s. 487-489.

${ }^{98}$ Bkz. LÓPEZ MARTÍN, s. 85. Öte yandan, Alexander'in, herhangi spesifik bir genişliğe yer vermeden anılan bu boğazı 24 deniz milinden geniş boğazlar listesine dâhil ettiği de unutulmamalıdır. Bkz. ALEXANDER, 1986, s. 203.

${ }^{99} \mathrm{Bu}$ yönlü seyrüsefersel ve/veya hidrografik engellere dair genel bir açıklama için bkz. LANGDON J.B.R.L., The Extent of Transit Passage: Some Practical Anamolies, Marine Policy, vol. 14/2, 1990, s. 130-136, özellikle s. 131-132.

${ }^{100}$ Bkz. RONZITTI N., Law of the Sea Aspects and Legal Policies of Naval Arms Control in the Mediterranean, International Spectator, vol. 28/4, 1993, s. 46 ve 72.

${ }^{101}$ Scovazzi de bu görüşü paylaşmaktadır. Bkz. SCOVAZZI, 1995, s. 151. 
Örgütünün Deniz Güvenliği Komitesinin 11 ilâ 20 Mayıs 2016 tarihleri arasında gerçekleştirilen 96. Oturumunda Korsika Boğazına ilişkin yeni trafik ayrım şemaları kabûl edilmiştir. ${ }^{102}$

İtalya'nın çevresindeki boğazlardan Otranto, Sicilya ve Malta Boğazları 24 deniz milinden daha geniş boğazlar konumundadır. ${ }^{103} \mathrm{Bu}$ çerçevede, ortalarında gemilerin serbestçe seyrüsefer gerçekleştirebileceği açık deniz veya en azından münhasır ekonomik bölge alanı bulunmaktadır. Tespit edilebildiği kadarıyla, bu boğazların ortasındaki bu açık deniz veya münhasır ekonomik bölge alanlarında seyrüseferi engelleyebilecek bir oluşum veya hidrografik bir özellik de bulunmamaktadır. Diğer bir deyişle, bu boğazlardan açık denizlerdeki serbest geçiş rejimi devam ettirilecektir. Hatırlanacağı üzere, III. Deniz Hukuku Konferansı öncesindeki görüşmelerde İtalyan Delegesi 19 Temmuz ilâ 27 Ağustos 1971 tarihleri arasında süre gelen Deniz Yatağı Komitesinde gerçekleştirdiği konuşmada 24 deniz mili genişliğini aşkın boğazlardaki serbest geçiş hakkının her türlü sınırlandırmadan muaf olması gerektiğini ve 12 deniz mili sınırın ötesindeki tüm deniz alanlarında olduğu gibi o boğazlarda da uluslararası kamuoyunun her zaman serbest denizlerin varlığını tanıması gerektiğini belirtmiştir. Nitekim, 1982 tarihli Birleşmiş Milletler Deniz Hukuku Sözleşmesi m. 36'da şu şekilde bir düzenleme mevcuttur: "Bu kısım hükümleri, seyrüsefer veya hidrografik özellikler bakımından geçilebilecek eşit uygunlukta bir açık deniz yolunun veya münhasır ekonomik bölge yolunun bulunduğu durumlarda, uluslararası seyrüsefer amacıyla kullanılan boğazlar hakkında uygulanmaz; ...”. Maddenin devamında bu tür boğazlara başta açık deniz hükümleri olmak üzere Sözleşmenin diğer ilgili kısım hükümlerinin uygulanacağ 1 belirtilmiştir. Vukas ise, taslak maddelerde bu şekilde bir hükmün bulunmadığını, bu şekilde bir hükmün getirilmesini uluslararası deniz ticaret trafiği bu nitelikteki bir boğazdan geçişe bağlı olan Yugoslavya tarafindan 1srarla talep edildiğini ve taslağa eklendiğini; amacının ise, bu tür boğazlarda, hiçbir şüpheye yer vermeyecek şekilde, gerek transit geçiş rejiminin, gerek askıya alınamayan zararsız geçiş rejiminin uygulanmaması olduğunu

\footnotetext{
102 Bkz. "Maritime Safety Committee (MSC), 96th Session, 11-20 May", May 252016 via www.imo.org/en/MediaCentre/MeetingSummaries/MSC/Pages/MSC-96th-session.aspx (ziyaret tarihi: 25/08/16).

${ }^{103}$ Hattâ, Ronzitti, aşırı genişliklerinden dolayı Sicilya ve Otranto Boğazlarını hukukî boğaz olmadıkları yönünde literatüre geçirmiştir. Bkz. RONZITTI, 1993, s. 46.
} 
vurgulamıştır. ${ }^{104}$ Nitekim, Yugoslavya'nın bu çabası, III. Deniz Hukuku Konferansının III. Bölüme ilişkin tutanaklarından da kolaylıkla takip edilebilmektedir. ${ }^{105}$.

Son olarak, İtalya'nın sadece bir kıyısına sahip olduğu boğazlardaki, diğer kıyıdaş devletle İtalya arasındaki sınırlandırmalara da değinilebilir. İtalya'nın, başka devletlerle birlikte kıyıdaşı olduğu dört boğazdan üçünü kapsayan sınırlandırma antlaşmaları yaptığı gözlenmektedir. Bunlar sirasıyla, Tunus-İtalya (1971) ${ }^{106}$, Fransa-İtalya $(1986)^{107}$ ve Arnavutluk-İtalya (1992) $)^{108}$ antlaşmalarıdır. Tunus ve Arnavutluk'la kıta sahanlığı sınırlandırılması söz konusuyken ${ }^{109}$, Fransa ile adı geçen antlaşmada iki devletin adaları arasında konumlanan Bonifacio Boğazında karasuları sınırlandırılmas ${ }^{110}$ gerçekleştirilmiştir.

104 Bkz. VUKAS B., The New Law of the Sea and Navigation: A View from the Mediterranean, in Law of the Sea: Selected Writings, edited by Vukas, Martinus Nijhoff Publishers, Leiden, 2004, s. 146-147.

${ }^{105}$ Bkz. "Straits ...", vol. II, s. 107, 114-115, 117, 118, 132 ve 153.

10620 Ağustos 1971 tarihinde akdedilen ve 6 Aralık 1978 tarihinde yürürlüğe giren "I $i k i$ Ülke Arasındaki Kıta Sahanlığının Sinırlandırılmasına İlişkin Tunus Cumhuriyeti Hükûmeti ile İtalyan Cumhuriyeti Hükûmeti Arasındaki Anlaşma". Bu anlaşmanın metni için bkz. CHARNEY J.I. \& ALEXANDER L.M. (eds.), International Maritime Boundaries, vol. II, Martinus Nijhoff Publishers, Dordrecht, 1996, s. 1621-1625.

10728 Kasım 1986 tarihinde imzalanarak 15 Mayıs 1989 tarihinde yürürlüğe giren "Bonifacio Boğazı Alanında Deniz Sinırlarının Sinırlandırılmasına Dair Fransız Cumhuriyeti Hükûmeti ile Italyan Cumhuriyeti Hükûmeti Arasındaki Anlaşma". Bu anlaşmanın metni için bkz. CHARNEY \& ALEXANDER, s. 1578-1580.

108 "İki Ülkenin Her Birinin Kıta Sahanlığının Belirlenmesi İçin Arnavutluk ve İtalya Arasındaki Anlaşma". İlgili bu anlaşmanın metni için bkz. viahttp://www.un.org/Depts/los/LEGISLATIONANDTREATIES/PDFFILES/TREATIE S/ALB-ITA1992CS.pdf (ziyaret tarihi: 15/08/16).

109 Tunus ile gerçekleştirilen sınırlandırmada iki ülke arasında eşit mesafe hattının kullanıldığı gözlenmektedir. Bu anlaşmaya dair daha ayrıntılı değerlendirmeler için bkz. AHNISH, s. 301-307; ARANGIO-RUIZ G., The Italian Shelf Delimitation. Agreements and the General Law on Shelf Delimitation, in Il regimo giuridico internazionale del mare Mediterraneo, edited by Leanza, Dott A. Giuffrè Editore, Milano, 1987, 33-57.; SCOVAZZI T. \& FRANCALANCI G., Italy-Tunisia, in International Maritime Boundaries, vol. II, edited by Charney \& Alexander, Martinus Nijhoff Publishers, Dordrecht, 1996, s. 1611-1619; TREVES, 1997, s. 354-355. Öte yandan, Arnavutluk ile 1992 y1lında gerçekleştirilen anlaşmada düzeltilmiş orta hat tercih edilmiştir. Bkz. TREVES, 1997, s. 356.

${ }^{110} \mathrm{Bu}$ sınırlandırmada açık olarak bir sınırlandırma metodu belirlenmemiş olsa da, sınır oluşturan hattın düzeltilmiş orta hat olduğu mütalâa edilmektedir. Bu anlaşmaya dair ayrıntılı değerlendirmeler için bkz. AHNISH, s. 287-288; SCOVAZZI T. \& FRANCALANCI G., France-Italy, in International Maritime Boundaries, vol. II, edited 
Malta ile ise, bu devletin İtalya'nın Sicilya ve İtalyan anakarasında sınırlandırma alanlarına denk gelen kıyılardaki bazı esas hatları kabûl etmeyeceğini açıklaması sonrasında bir sınırlandırmaya, en azından henüz, gidilememiştir.

\section{Sonuc}

Akdeniz'in ortasındaki konumu ve çalışmanın içeriğini de teşkil eden yedi boğazıyla önemli bir boğaz devleti durumundaki İtalya'nın, her ne kadar kıyısının olduğu bu boğazlara ilişkin jeopolitik konumu ve bu bağlamda coğrafî nitelikleri itibarıyla sorun yaşamayacağ düşünülebilecekse de, gerek III. Deniz Hukuku Konferansındaki tutumu ve önerilerinin, gerek 1982 Birleşmiş Milletler Deniz Hukuku Sözleşmesi çerçevesindeki uygulamalarının değerlendirilmesinin kuşkusuz yine de önemi yadsınamayacaktır. Bu çerçevede, yapılan incelemede görüldüğü üzere, İtalya'nın III. Deniz Hukuku Konferansında aktif ve etkin bir rol oynayarak uluslararası seyrüseferde kullanılan boğazlara dair birtakım düzenlemelere yön verdiği gözlenmektedir. Özellikle, kendi stratejik çıkarları doğrultusunda kabûl ettirdiği Messina istisnası (m. 38/1) bu durumun en temel örneğini oluşturmaktadır.

1982 Birleşmiş Milletler Deniz Hukuku Sözleşmesinin uygulanmasına gelindiğinde, İtalya'nın genel olarak ilgili hükümlere uygun davrandığı gözlense de, bazı istisnaî durumlarda aykırılıkların ve ayrıklıkların yaşandığ protestolarıyla karşılaşıldığ 1 da bir gerçektir. Bunun haricinde, İtalya, 1982 Birleşmiş Milletler Deniz Hukuku Sözleşmesi III. Bölüm çerçevesindeki uygulamaları "zaruret hâli” gibi genel uluslararası hukuk ilkelerine dayanarak ${ }^{111}$ ve uluslararası gelişmelere de uygun olarak kendi lehine daha da olumlu hâle getirmeyi de bilmiştir.

Kısaca, boğazlara ilişkin çok akılcı ve etkin bir yol izleyen İtalya, III. Deniz Hukuku Konferans1 sonunda kabûl edilen 1982 tarihli Birleşmiş Milletler Deniz Hukuku Sözleşmesinde konuya ilişkin olarak kendi çıkarları doğrultusunda düzenlemeleri kabûl ettirtebilmesinin yanı sıra, sonrasında gerektiğinde bu kuralları yine kendi lehine başarılı bir biçimde esnetebilmiş de görünmektedir.

by Charney \& Alexander, Martinus Nijhoff Publishers, Dordrecht, 1996, s. 1571-1576; TREVES, 1997, s. 353.

111 “Zaruret hâli”ni İtalyan Devleti değil, İtalyan hukukçular öne sürmektedir. 


\section{Bibliografya}

\section{Aslî Kaynaklar}

1958 tarihli Cenevre Karasuları ve Bitişik Bölge Sözleşmesi.

1958 tarihli Cenevre Kita Sahanlığı Sözleşmesi.

1958 tarihli Cenevre Açık Denizler Sözleşmesi.

1958 tarihli Cenevre Balıkçılık ve Açık Denizlerdeki Canlı Kaynakların Korunması Sözleşmesi.

1971 tarihli İki Ülke Arasındaki Kıta Sahanlığının Sınırlandırılmasına İlişkin Tunus

Cumhuriyeti Hükûmeti ile İtalyan Cumhuriyeti Hükûmeti Arasındaki Anlaşma.

1974 tarihli1942 tarihli Seyrüsefer Kanuna Değişiklik Getiren 359 sayılı Kanun

1982 tarihli Birleşmiş Milletler Deniz Hukuku Sözleşmesi.

1986 tarihli Bonifacio Boğazı Alanında Deniz Sınırlarının Sınırlandırılmasına Dair Fransız Cumhuriyeti Hükûmeti ile İtalyan Cumhuriyeti Hükûmeti Arasındaki Anlaşma.

1992 tarihli İki Ülkenin Her Birinin Kıta Sahanlığının Belirlenmesi İçin Arnavutluk ve İtalya Arasındaki Anlaşma.

1993 tarihli Deniz Ticaret Bakanlığı Kararnâmesi.

1993 tarihli Fransız Kararnâmesi.

1993 tarihli Uluslararası Denizcilik Örgütü A 766(18) sayılı Kararı.

2006 tarihli Ekolojik Koruma Bölgesi Oluşturulmasına Yönelik Kanun.

2011 tarihli Ekolojik Koruma Bölgesine Yönelik Başkanlık Kararnâmesi.

\section{Talî Kaynaklar: Kitap ve Makaleler}

ABBADI A.K., Security and Cooperation in the Mediterranean Basin, Ocean Development \& International Law, vol. 14/4, 1984, s. 55-78.

AHNISH F.A., The International Law of Maritime Boundaries and the Practice of States in the Mediterranean Sea, Oxford University Press, Oxford, 1993.

ALEXANDER L.M., Regionalism and the Law of the Sea: The Case of Semi Enclosed Seas, Ocean Development \& International Law, vol. 2/2, 1974, s. 151-186.

ALEXANDER L.M., Navigational Restrictions within the New LOS Convention: Geographical Implications for the United States, Offshore Consultants Inc., Rhode Island, 1986.

ALEXANDER L.M., Exceptions to the Transit Passage Regime: Straits with Routes of "Similar Convenience", Ocean Development \& International Law, vol. 18/4, 1987, s. 479-491.

ARANGIO-RUIZ G., The Italian Shelf Delimitation. Agreements and the General Law on Shelf Delimitation, in Il regimo giuridico internazionale del mare Mediterraneo, edited by Leanza, Dott A. Giuffrè Editore, Milano, 1987, 33-57.

BLAKE G.H., Mediterranean Micro-Territorial Disputes and Maritime Boundary Delimitation, in Il regimo giuridico internazionale del mare Mediterraneo, edited by Leanza, Dott A. Giuffrè Editore, Milano, 1987, s. 111-117. 
BOCZEK B.A., The A to $\mathrm{Z}$ of International Law, Lanham, 2010.

BORDUNOV V.D., The Right of Transit Passage under the 1982 Convention, Marine Policy, vol. 12/3, 1988, s. 219-230.

BRÜEL E., International Straits-A Treatise on International Law: The General Legal Position of International Straits, NYT Nordisk Forlag/Sweet \& Maxwell Ltd., Copenhagen, 1947.

CAMINOS H. \& COGLIATI-BANTZ V.P., The Legal Regime of the Straits: Contemporary Challenges and Solutions, Cambridge University Press, Cambridge, 2014.

CAMINOS H. \& MOLITOR M.R., Progressive Development of International Law and the Package Deal, American Journal of International Law, vol. 79/4, 1985, s. 871-890.

CHARNEY J.I. \& ALEXANDER L.M. (eds.), International Maritime Boundaries, vol. II, Martinus Nijhoff Publishers, Dordrecht, 1996.

ÇAMYAMAÇ A., Denize Kıyısı Olmayan ve Coğrafî Açıdan Elverişsiz Devletlerin Hukukî Durumu, Adalet Yayınevi, Ankara, 2012.

DURANTE F., Italy, in New Directions in the Law of the Sea: Collected Papers, vol. III, edited by Churchill \& Simmonds \& Welch, Oceana Publications Inc., London, 1973, s. 266-270.

EVENSEN J., The Working Methods and Procedures in the Third United Nations Conference on the Law of the Sea, Recueil des cours, vol. 199, 1986IV, 1986, s. 415-520.

FENN P.T.Jr., Origins of the Theory of Territorial Waters, American Journal of International Law, vol. 20/3, 1926, s. 465-482.

FÜßER K. \& LAU M. \& NASTASI G., Bridge over the Straits of Messina, Journal for European Environmental \& Planning Law, vol. 7/3, 2010, s. 245266.

GESTRI M., The Legal Regime of Navigation through the Strait of Messina, Marine Pollution Bulletin, vol. 19/8, 1988, s. 354-355.

GHOSH S., Superpower Co-Operation and Transit Passage through Straits, Economic \& Political Weekly, vol. 20/18, 1985, s. 807-811.

GIOIA A., Gulf of Aqaba, Max Planck Encyclopedia of Public International Law, online edition, Wolfrum, 2010 via www.mpepil.com (ziyaret tarihi: 08/10/10).

GIULIANO M., The Regime of Straits in General International Law, Italian Yearbook of International Law, vol. 1, 1975, s. 16-26.

GRBEC M., Extension of Coastal State Jurisdiction in Enclosed and Semi-Enclosed Seas: A Mediterranean and Adriatic Perspective, Routledge, Oxon, 2014.

HAQUE E. \& HASSAN D., Maritime Boundary Delimitation: A Normative Standard? Part I: Historical Development of the Legal Regime, Environmental Policy \& Law, vol. 44/5, 2014, s. 433-450.

JIA B.B., The Regime of Straits in International Law, Oxford University Press, New York, 1998.

KENNEDY R.H., A Brief Geographical and Hydrographical Study of Straits Which Constitute Routes for International Traffic, United Nations Conference on the Law of the Sea-Official Documents vol. I: Preparatory Documents, Document A/CONF.13/6 and Add. 1, Geneva, 1958, s. 114-164. 
LANGDON J.B.R.L., The Extent of Transit Passage: Some Practical Anamolies, Marine Policy, vol. 14/2, 1990, s. 130-136.

"Limits of Oceans and Seas", 3rd edition, International Hydrographic Organization Special Publication no: 28, Monte Carlo, 1953.

LÓPEZ MARTÍN A.G., International Straits: Concept, Classification and Rules of Passage, Springer, Heidelberg, 2010.

MAHMOUDI S., Transit Passage, Max Planck Encyclopedia of Public International Law, on-line edition, edited by Wolfrum, 2010 via www.mpepil.com (ziyaret tarihi: 04/10/10).

MOLENAAR J., Navigational Rights and Freedoms in a European Regional Context, in Navigational Rights and Freedoms and the New Law of the Sea, edited by Rothwell \& Bateman, Martinus Nijhoff Publishers, Dordrecht, 2000, s. 22-46.

NANDAN S.N. \& ANDERSON D.H., Straits Used for International Navigation: A Commentary on Part III of the United Nations Convention on the Law of the Sea 1982, British Yearbook of International Law, vol. 60, 1989, s. 159-204.

ÖZBEK D., Article 35(c) Straits of the UN Law of the Sea Convention, in Navigating Straits: Challenges for International Law, edited by Caron \& Oral, Brill Nijhoff, Leiden, 2014, s. 190-198.

ÖZMAN A., Deniz Hukuku I: Kaynaklar, Kişiler, Nesneler, Ulusal Deniz Alanları, Turhan Kitabevi, Ankara, 2006.

PELLET A., The British Sovereign Base Areas, Cyprus Yearbook of International Law, 2012, s. 57-72.

PHARAND D., International Straits, Thesaurus Acroasium, vol. 7, 1977, s. 59-100.

QUÉGUINER J., The Mediterranean as a Maritime Trade Route, Ocean Management, vol. 3/2, 1978, s. 179-189.

REISMAN W.M., The Regime of Straits and National Security: An Appraisal of International Lawmaking, American Journal of International Law, vol. 74/1, 1980, s. 48-76.

ROACH J.A. \& SMITH R.W., Excessive Maritime Claims, 3rd edition, Martinus Nijhoff Publishers, Leiden, 2014.

RONZITTI N., Is the Gulf of Taranto an Historic Bay?, Syracuse Journal of International Law \& Commerce, vol. 11/2\&3, 1984, s. 275-296.

RONZITTI N., New Criticism on the Gulf of Taranto Closing Line: A Restatement of a Different View, Syracuse Journal of International Law \& Commerce, vol. 12/3, 1986, s. 465-472.

RONZITTI N., Law of the Sea Aspects and Legal Policies of Naval Arms Control in the Mediterranean, International Spectator, vol. 28/4, 1993, s. 39-72.

"Sailing Directions (En Route)-Western Mediterranean", publication no: 131, 16th edition, $\quad$ Virginia, 2014

http://msi.nga.mil/MSISiteContent/StaticFiles/NAV_PUBS/SD/Pub13 1/Pub131bk.pdf (ziyaret tarihi: 01/09/16).

SANGER C., Ordering the Oceans: The Making of the Law of the Sea, University of Toronto Press, Avon, 1987.

SANTACROCE R. \& CRISTOFOLINI R. \& La VOLPE L. \& ORSI G. \& ROSI M., Italian Active Volcanoes, Episodes, vol. 26/3, 2003. 
SCOVAZZI T., Implications of the New Law of the Sea for the Mediterranean, Marine Policy, vol. 5/4, 1981, s. 302-312.

SCOVAZZI T., International Law of the Sea as Applied to the Mediterranean, Ocean \& Coastal Management, vol. 24/1, 1994, s. 71-81.

SCOVAZZI T., Management Regime and Responsibility for International Straits with Special Reference to the Mediterranean Straits, Marine Policy, vol. 19/2, 1995, s. 137-152.

SCOVAZZI T., The Strait of Messina and the Present Regime of International Straits, in Navigating Straits: Challenges for International Law, edited by Caron \& Oral, Brill Nijhoff, Leiden, 2014, s. 138-150.

SCOVAZZI T. \& FRANCALANCI G., France-Italy, in International Maritime Boundaries, vol. II, edited by Charney \& Alexander, Martinus Nijhoff Publishers, Dordrecht, 1996, s. 1571-1576.

SCOVAZZI T. \& FRANCALANCI G., Italy-Tunisia, in International Maritime Boundaries, vol. II, edited by Charney \& Alexander, Martinus Nijhoff Publishers, Dordrecht, 1996, s. 1611-1619.

SELAK C.B.Jr., A Consideration of the Legal Status of the Gulf of Aqaba, American Journal of International Law, vol. 52/4, 1958, s. 660-698.

SERŠIĆ M., The Adriatic Sea: Semi-Enclosed Sea in a Semi-Enclosed Sea, in $\mathbf{L a}$ Méditerranée et le droit de la mer à l'aube du 21e siècle/The Mediterranean and the Law of the Sea at the Dawn of the 21st Centruy, edited by Cataldi, Bruylant, Bruxelles, 2002, s. 329-347.

SHARMA O.P., The International Law of the Sea: India and the UN Convention of 1982, Oxford University Press, New Delhi, 2009.

"Straits Used for International Navigation-Legislative History of Part III of the United Nations Convention on the Law of the Sea", volume I, United Nations: Office for Ocean Affairs and the Law of the Sea, New York, 1992.

"Straits Used for International Navigation-Legislative History of Part III of the United Nations Convention on the Law of the Sea", volume II, United Nations: Division for Ocean Affairs and the Law of the Sea Office of Legal Affairs, New York, 1992.

SPADI F., The Bridge on the Straits of Messina: "Lowering" the Right of Innocent Passage?, International \& Comparative Law Quarterly, vol. 50/2, 2001, s. 411-419.

SWARZTRAUBER S.A., The Three-Mile Limit of Territorial Sea, Naval Institute Press, Annapolis, 1972.

TREVES T., Transit Passage and Protection of the Environment in the Strait of Bonifacio, in $\boldsymbol{A}$ Law for the Environment: Essays in Honour of Wolfgang $E$. Burhenne, edited by Kiss \& Burhenne-Guilmin, IUCN: The World Conservation Union, Norwich, 1994, s. 121-129.

TREVES T., Italy and the Law of the Sea, in The Law of the Sea: The European Union and Its Member States, edited by Treves \& Pineschi, Martinus Nijhoff Publishers, The Hague, 1997, s. 327-363.

TREVES T. \& PAPANICOLOPULU I., The Law Applicable on the Continental Shelf and in the Exclusive Economic Zone: The Italian Perspective, Ocean Yearbook, vol. 25, 2011, s. 347-356.

TRUVER S.C., The Strait of Gibraltar and the Mediterranean, Sijthoff \& Noordhoff, Alphen aan den Rijn, 1980. 
VIO I., The Strait of Otranto, in The Proceedings of the Symposium on the Straits Used for International Navigation, edited by Öztürk \& Özkan, Ofis Matbaas1, İstanbul, 2002, s. 62-71.

VUKAS B., The New Law of the Sea and Navigation: A View from the Mediterranean, in Law of the Sea: Selected Writings, edited by Vukas, Martinus Nijhoff Publishers, Leiden, 2006, s. 133-154.

WESTERMAN G., The Juridical Status of the Gulf of Taranto: A Brief Reply, Syracuse Journal of International Law \& Commerce, vol. 11/2\&3, 1984, s. 297-309.

ZEIDAN A.L., The Emergence of the Gulf of Aqaba Problem, Revue égyptienne de droit international, vol. 35, 1979, s. 1-65. 